\title{
Mechanisms of passivation and chloride-induced corrosion of mild steel in sulfide-containing alkaline solutions
}

\author{
Shishir Mundra ${ }^{1,2,3}$ (1) and John L. Provis ${ }^{1, *}$ (1) \\ ${ }^{1}$ Department of Materials Science and Engineering, The University of Sheffield, Sir Robert Hadfield Building, Mappin Street, \\ Sheffield S1 3JD, UK \\ ${ }^{2}$ Technology of Construction Materials, Bundesanstalt für Materialforschung und -prüfung (BAM), Unter den Eichen 87, \\ 12205 Berlin, Germany \\ ${ }^{3}$ Institute for Building Materials (IfB), ETH Zurich, Stefano-Franscini-Platz 3, 8093 Zurich, Switzerland
}

Received: 24 February 2021

Accepted: 4 June 2021

Published online:

16 June 2021

(C) The Author(s) 2021

\begin{abstract}
The pore fluid within many concretes is highly alkaline and rich in reduced sulfur species, but the influence of such alkaline-sulfide solutions on the surface film formed on steel reinforcement is poorly understood. This study investigates the critical role of $\mathrm{HS}^{-}$in defining mild steel passivation chemistry. The surface film formed on the steel in alkaline-sulfide solutions contains $\mathrm{Fe}(\mathrm{OH})_{2}$ and $\mathrm{Fe}-\mathrm{S}$ complexes, and the critical chloride concentration to induce corrosion increases at high sulfide concentration. However, this behavior is dependent on the duration of exposure of the steel to the electrolyte, and the nature of the sulfidic surface layer.
\end{abstract}

\section{Introduction}

As part of the global move toward reducing $\mathrm{CO}_{2}$ emissions from Portland cement (PC) production, and to produce highly durable concretes for demanding (e.g., marine) applications, PC is increasingly being substituted with ground-granulated blast furnace slag, a by-product of the ironmaking process. Innovative cements such as alkaliactivated slags (AAS), produced by the reaction between slags and an alkaline solution [1], are also a viable alternative to PC-based binders for specific applications. The reducing nature of the blast furnace is retained by the slag, which contains $\sim 1-3$ wt $\%$ sulfur, mostly in a reduced state and available to dissolve when mixed with water or an alkaline solution [2-4]. As critical infrastructure applications depend on the use of steel-reinforced concretes, the uptake of alternative construction materials such as PC-slag blends and AAS in these applications is challenged by the incomplete understanding of the susceptibility of steel to chloride- or carbonation-induced corrosion in the presence of high

Handling Editor: P. Nash.

Address correspondence to E-mail: j.provis@sheffield.ac.uk 
concentrations of sulfide. The concentration of reduced sulfur species (mainly present as $\mathrm{HS}^{-}$) in AAS has been measured to be around $\sim 0.45 \mathrm{M}$ $[2,3]$, much higher than in more conventional PCslag blends, and this extremely high concentration is expected to be important in understanding both the cement chemistry and the susceptibility of reinforcing steel to corrosion within concretes made from these binders.

Similar concerns regarding the corrosion of iron and steel in aqueous-sulfide solutions have been addressed in the literature pertaining to various industrial processes such as the Kraft process in the pulp industry [5], the Girdler sulfide process in the production of heavy water [6], in the oil and gas industry [7], and in environments with metabolic activity of sulfate reducing bacteria [8]. Unlike most of the aforementioned processes, the $\mathrm{pH}$ of the pore fluid within cementitious materials is between 12.5 and 14 , which limits the transferability of mechanistic information obtained in near-neutral or acidic environments. Considering the enormous costs associated with the corrosion of critical infrastructure (i.e., direct and indirect costs amounting to $\sim 6 \%$ of U.S. GDP [9]), it is essential that the long-term durability of modern infrastructure materials is better understood.

The steel-concrete interface provides a highly alkaline environment enabling the formation of a protective/passive film on the surface of a mild steel reinforcement. The passive film formed in most cementitious binders without high sulfide concentrations is composed, in the general sense, of an inner layer of ferrous hydroxide $\left(\mathrm{Fe}(\mathrm{OH})_{2}\right)$ that can readily oxidize to form magnetite $\left(\mathrm{Fe}_{3} \mathrm{O}_{4}\right)$, and an outer layer composed of $\mathrm{Fe}(\mathrm{OH})_{3}$ or hydrated Fe (III) oxide $\left(\mathrm{Fe}_{2} \mathrm{O}_{3} \cdot n \mathrm{H}_{2} \mathrm{O}\right)$ [10]. However, the exact composition of the passive film formed on mild steel in alkaline conditions has been a subject of debate throughout the literature [11] and depends on the chemistry and $\mathrm{pH}$ of the electrolyte, and the availability of oxygen [12]. Therefore, the presence of $\mathrm{HS}^{-}$in addition to $\mathrm{OH}^{-}$would alter the chemistry of the passive film and thereby have consequences on the susceptibility of the steel to chloride-induced corrosion [13-16]. Fe in the passive film of mild steel was reported to be in the $2+$ oxidation state when in contact with PC-slag blends, rather than in the 3 + oxidation state observed in plain PC [4]. Based on previous observations of higher porosity of the $\mathrm{Fe}(\mathrm{II})$ oxides in comparison with Fe(III) oxides [17], it has been suggested that cements with replacement of PC with slag did not generate a passive film on the steel reinforcement, thus giving lower protection against corrosion by aggressive ions such as $\mathrm{Cl}^{-}$[4]. There is also a significant decrease in the redox potentials of steel reinforcement in PC-slag blends with $>75 \%$ replacement of PC with slag $[4,18]$, primarily due to the release of reduced sulfur species. A recent study [14] (also highlighted in [4, 18, 19]) showed that the highly reducing nature of the slag limits the concentration of dissolved oxygen, yielding significantly lower electrochemical potentials of the steel reinforcement embedded in PC-slag blends compared to plain PC.

The onset of chloride-induced corrosion of the steel reinforcement is often described by the concept of chloride "threshold" value $\left(C_{\text {crit }}\right)$, defined as the minimum concentration of chloride that initiates depassivation [20]. This is often characterized electrochemically by either a drop in the redox potential and polarization resistance, or an increase in the corrosion current density. Published data on the chloride threshold values for steel embedded in PCslag blends are contradictory and are scattered [20]. Some studies have indicated the $C_{\text {crit }}$ to be much higher in the case of PC-slag blends than for plain PC [21, 22], whereas others have reported the converse $[13,23,24]$, or no significant differences in $C_{\text {crit }}$ [25]. $C_{\text {crit }}$ values measured for steel reinforcement in $\mathrm{Na}_{2}$ $\mathrm{SiO}_{3}$-activated fly ash/slag blends were observed to be the lowest for binders produced with higher amounts of slag, i.e., with a more reducing internal environment [26]. However, electrochemical investigations of steel reinforcement in AAS with admixed chloride levels of up to $8 \mathrm{wt} \%$ of binder reported no pitting even at very high chloride concentrations [27]. The oxidation of HS $^{-}$present in the pore solution of AAS was suggested to play a critical role in the mechanisms of passivation/depassivation and the long term-performance of these binders [27].

In light of such diverging evidence, it is important that the role of reduced sulfur species in steel corrosion is addressed with care. This study focusses on the influence of reduced sulfur species on the mechanisms of passivation of steel, and localized corrosion due to chlorides, in highly alkaline solutions $(0.80 \mathrm{M}$, $1.12 \mathrm{M}$ and $1.36 \mathrm{M} \mathrm{NaOH}$ ) containing $0.01 \mathrm{M}, 0.09 \mathrm{M}$ and $0.45 \mathrm{M} \mathrm{HS}^{-}$, via electrochemical and spectroscopic techniques. 


\section{Experimental program}

\section{Materials}

The steel reinforcement bars used in this research were mild steel, grade B500 according to ISO/DIS 6935-2 [28], with a chemical composition (measured through X-ray fluorescence (XRF) and standard deviation of 0.03 wt \%): 97.91 wt $\% \mathrm{Fe}, 0.21$ wt \% C, 0.13 wt $\% \mathrm{Cr}, 0.20$ wt $\% \mathrm{Ni}, 0.47$ wt $\% \mathrm{Cu}, 0.23$ wt $\%$ Si, 0.76 wt $\% \mathrm{Mn}, 0.03$ wt $\%$ S, 0.02 wt $\%$ Mo, and 0.04 wt $\%$ P. The steel bars $(\varphi=12 \mathrm{~mm})$ were obtained from a local supplier in Sheffield, UK. The rebars were cut into small disks, with a thickness ranging between 5.5 and $6.5 \mathrm{~mm}$, using an abrasive disk. Prior to electrochemical testing, the disk surfaces were polished using $\mathrm{SiC}$ abrasive paper with 240 to 600 grit sizes, and degreased using acetone, to achieve a roughness of $R_{a}=0.14 \mu \mathrm{m}$ (measured using ContourGT-X 3D Optical Profiler). The steel used in this study and the preparation of the small disk specimens is identical to those used in [10].

ACS reagent grade $\mathrm{NaOH}$ pellets (Sigma-Aldrich), $\mathrm{Na}_{2} \mathrm{~S} \cdot 9 \mathrm{H}_{2} \mathrm{O}$ (Alfa Aesar) and commercial grade $\mathrm{NaCl}$ (EMD Chemicals) were used to synthesize alkaline solutions with specific concentrations of sulfur. The dissolved sulfur is represented as $\mathrm{HS}^{-}$(aq.), although it would be reasonable to expect trace formation of $\mathrm{S}_{\mathrm{n}}{ }^{2-}$ (aq.), $\mathrm{SO}_{3}{ }^{2-}$ (aq.), $\mathrm{S}_{2} \mathrm{O}_{3}{ }^{2-}$ (aq.), and $\mathrm{SO}_{4}{ }^{2-}$ (aq.) due to the dissolved oxygen present, consistent with the literature for extracted AAS pore solutions [2]. The upper limit of $\left[\mathrm{HS}^{-}\right]$was set to $0.45 \mathrm{M}$, to be representative of pore solutions of AAS $[2,3]$. The compositions of the solutions used in this study are shown in "Passivation" and "X-ray photoelectron spectroscopy" sections.

All electrochemical tests were conducted in a 400-mL corrosion cell using a PGSTAT 204 potentiostat/galvanostat (Metrohm Autolab B.V.), as used in [10]. Measurements were conducted using a conventional three-electrode setup (electrolyte volume $250 \mathrm{~mL}$ ), comprising a stainless steel counter electrode, an $\mathrm{Ag} / \mathrm{AgCl}$ (saturated $3 \mathrm{M} \mathrm{KCl}$ ) reference electrode, and the mild steel surface (surface area: $0.287 \mathrm{~cm}^{2}$ ) acting as the working electrode (Figure S1, Supplementary Information) [10]. The steel surface tested was the cut surface, not curved rebar surface. The reference electrode was positioned near the surface of the working electrode by means of a Luggin capillary. All measurements were conducted at room temperature $\left(22 \pm 2{ }^{\circ} \mathrm{C}\right)$ on at least two samples to ensure reproducibility.

\section{Passivation}

\section{Cyclic voltammetry}

Cyclic voltammetry (CV) was conducted to characterize the passive film formed on the steel surface when exposed to solutions containing $0.80 \mathrm{M} \mathrm{OH}^{-}$ and varying concentrations of $\mathrm{HS}^{-}(0 \mathrm{M}, 0.01 \mathrm{M}$ and $0.45 \mathrm{M}$ ). Additionally, to understand the influence of $\mathrm{OH}^{-}$in sulfide-containing electrolytes, $\mathrm{CV}$ was also conducted on mild steel disk specimens exposed to solutions with increased concentrations of $\mathrm{OH}^{-}$ (1.12 $\mathrm{M}$ and $1.36 \mathrm{M}$ ) with $0.01 \mathrm{M} \mathrm{HS}^{-}$. The parameters used to conduct $\mathrm{CV}$ in this study are identical to the ones used in [10]. Before starting each test, the steel was held at $-1.50 \mathrm{~V}$ versus $\mathrm{Ag} / \mathrm{AgCl}$ (cathodic limit: $E_{\lambda, c}$ ) in the hydrogen evolution region for $10 \mathrm{~min}$ to ensure electrochemical cleaning of the surface of the steel [10]. The electrochemical response of the system was recorded when the potential was cycled from - $1.50\left(\mathrm{E}_{\lambda, \mathrm{c}}\right)$ to $0.65 \mathrm{~V}$ (anodic limit: $\left.\mathrm{E}_{\lambda, a}\right)$, at a scan rate of $2.5 \mathrm{mV} / \mathrm{s}$ for 5 cycles, taking into account hydrogen and oxygen evolution at the cathodic and anodic limits, respectively [10].

\section{Open-circuit potential, linear polarization resistance and anodic polarization}

Mild steel disk specimens were exposed to solutions containing $0.80 \mathrm{M} \mathrm{OH}^{-}$and varying concentrations of $\mathrm{HS}^{-}(0 \mathrm{M}, 0.001 \mathrm{M}, 0.01 \mathrm{M}, 0.09 \mathrm{M}$ and $0.45 \mathrm{M})$ in Parafilm-sealed plastic vials within a vacuum desiccator, for $0,5,12$ and 28 days, prior to electrochemical testing. After each exposure duration, the steel specimens were transferred to the cell for electrochemical testing in fresh electrolytes prepared with a chemical composition matching the respective exposure solution.

Electrochemical techniques were applied to each of the steel specimens at each exposure time in the following order: (1) Open-circuit potential (OCP), (2) linear polarization resistance (LPR) and (3) anodic polarization. The parameters for each of the electrochemical techniques were identical to those used in [10].

Prior to any electrochemical polarization technique being applied, each sample was allowed to stabilize 
in the electrolyte inside the corrosion cell for $15 \mathrm{~min}$ prior to testing [10]. The OCP was recorded for $30 \mathrm{~min}$ in the beginning of each experiment unless the change in potential with time $(d V / d t)$ reached $\leq 1 \mu \mathrm{V} / \mathrm{s}$ before $30 \mathrm{~min}$. The OCP value reported in each case is the mean potential recorded during the last $60 \mathrm{~s}$ of the test [10].

LPR measurements were carried out by varying the potential from -20 to $+20 \mathrm{mV}$ versus the OCP (scan rate of $0.167 \mathrm{mV} / \mathrm{s}$ and step potential $0.244 \mathrm{mV}$ ), and the current response was recorded [10]. The polarization resistance $\left(R_{p}\right)$ was calculated using the modified Stern-Geary equations, Eqs. (1) and (2):

$R_{p}=\left(\frac{\Delta E}{\Delta I}\right)_{\Delta E \rightarrow 0}$

$i_{\text {corr }}=\frac{B}{R_{p}}$

where $\Delta E$ and $\Delta I$ are the changes in potential and current, respectively, $i_{\text {corr }}$ is the corrosion current density $\left(\mathrm{A} / \mathrm{cm}^{2}\right)$, and $B$ is a proportionality constant $(V)$. From Eq. 1, the polarization resistance was calculated by measuring the slope of the E-I plot [10].

The specimens were anodically polarized by varying the potential from the OCP to $+1.0 \mathrm{~V}$ with the step potential and scan rate set at $0.244 \mathrm{mV}$ and $0.167 \mathrm{mV} / \mathrm{s}$, respectively, and the corresponding current density was recorded [10].

\section{X-ray photoelectron spectroscopy}

Steel specimens were exposed to $0.80 \mathrm{M} \mathrm{OH}^{-}$solutions with $0.01 \mathrm{M}, 0.09 \mathrm{M}$, and $0.45 \mathrm{M} \mathrm{HS}^{-}$in Parafilm-sealed plastic vials within a vacuum desiccator, for 5, 12 and 28 days. After each exposure duration, the steel specimens were dried in nitrogen, then wrapped in Parafilm and transferred to an airtight container for transport to the X-ray photoelectron spectroscopy (XPS) facility. The specimens were then unwrapped, mounted onto the sample holder using double-sided sticky conducting tape, and loaded into the Kratos AXIS Supra spectrometer for the measurements to be carried out under ultra-high vacuum.

All measurements were carried out using an achromatic $\mathrm{Al} \mathrm{K} \alpha \mathrm{X}$-ray source, and data were acquired from three points (each with diameter $800 \mu \mathrm{m})$ per specimen. Survey scans were collected from 1200 to $0 \mathrm{eV}$ binding energy, with a pass energy of $160 \mathrm{eV}$, a step size of $1 \mathrm{eV}$, and an acquisition time of $5 \mathrm{~min}$ for each measurement. High-resolution XPS spectra were collected for iron (Fe $2 p)$, oxygen (O $1 s)$, carbon (C $1 s$ ) and sulfur (S $2 p$ ), with a pass energy of $20 \mathrm{eV}$ and a step size of $0.1 \mathrm{eV}$ for each measurement point over the appropriate energy range. The $\mathrm{O} 1 \mathrm{~s}$ and $C 1 s$ spectra were collected with 5 min acquisition time, whilst $S 2 p$ spectra was collected as two sweeps of $5 \mathrm{~min}$ each and averaged, due to its lower sensitivity. The Fe $2 p$ spectra were also collected as two sweeps of $5 \mathrm{~min}$ each and averaged, due to the broader energy range of this peak. The intensity of the acquired data was calibrated using a transmission function characteristic of the spectrometer (determined using software from NPL). Casa-XPS software (version 2.3.18PR1.0) was used to deconvolute and curve-fit the spectra.

All high-resolution spectra were first calibrated to the C $1 \mathrm{~s}$ signal at $284.8 \mathrm{eV}$. Optimal spectral basal line and peaks were determined using the Shirley background correction algorithm provided within the software [29]. The $2 p$ spectrum of Fe consists of two peaks (a doublet structure), Fe $2 p_{3 / 2}$ and Fe $2 p_{1 / 2}$, separated by approximately $13.8 \mathrm{eV}$ [29]. Due to the occurrence of satellite peaks between the two peaks, only the Fe $2 p_{3 / 2}$ peak was deconvoluted and curve fitted. The $S 2 p$ spectrum also consists of a doublet structure; however, the separation between the $S 2 p_{3 / 2}$ and $\mathrm{S} 2 p_{1 / 2}$ is much smaller $(\sim 1.18 \mathrm{eV})$ [30], and therefore, both peaks were analyzed in this study. The full width at half maximum (FWHM) of the $S 2 p_{1 /}$ 2 peak was constrained to be half of the $S 2 p_{3 / 2}$, and the position of the $S 2 p_{1 / 2}$ peak was constrained to be $1.18 \mathrm{eV}$ greater than the S $2 p_{3 / 2}$ peak. A $80 \%$ Gaussian, $20 \%$ Lorentzian peak model was used to fit the Fe $2 p_{3 / 2}$ and $S 2 p$ spectrums, as adopted by [30,31].

\section{Depassivation}

An exposure scheme similar to that described in "Open circuit potential, linear polarization resistance and anodic polarization" section was employed to investigate the mechanism of chloride-induced corrosion of mild steel in sulfide-containing alkaline solutions. Steel specimens were exposed to each of the test solutions without chloride (Table 1) in Parafilm-sealed plastic vials within a vacuum desiccator, for $0,5,12$ and 28 days prior to electrochemical testing. After each exposure time, fresh electrolytes 
with the same composition as the exposure solution were prepared, with the addition of $\mathrm{NaCl}$ at molar ratios $\left[\mathrm{Cl}^{-}\right] /\left[\mathrm{OH}^{-}\right]$between 0 and 4.0, 0 and 3.5, and 0 and 3.5 for solutions $0.80 \mathrm{M} \mathrm{OH}^{-}, 1.12 \mathrm{M} \mathrm{OH}^{-}$, and $1.36 \mathrm{M} \mathrm{OH}^{-}$, respectively.

Testing for OCP and anodic polarization was conducted on these samples according to the methodology described in "Open circuit potential, linear polarization resistance and anodic polarization" section.

\section{Results and discussion}

\section{Passivation}

\section{Cyclic voltammetry}

Figure 1 shows five cyclic voltammetry scans obtained for polished mild steel surfaces exposed to highly alkaline solutions $(0.80 \mathrm{M} \mathrm{NaOH})$, as a function of the sulfide concentration $(0 \mathrm{M}, 0.01 \mathrm{M}$ and $0.45 \mathrm{M} \mathrm{HS}^{-}$) in the electrolyte. An increase in the potential in the positive direction from $E_{\lambda, c}$ to $-1.20 \mathrm{~V}$ resulted in a significant increase in the current density of the steel related to the evolution of hydrogen bubbles at the steel surface and in the solution (not shown in Fig. 1). The passivation mechanism in alkaline solution without $\mathrm{HS}^{-}$(shown in Fig. 1a) has already been discussed in [10], and therefore will only be briefly revisited here.

In the case of mild steel immersed in alkaline solutions without $\mathrm{HS}^{-}$(Fig. 1a), four anodic current peaks were observed on increasing the potential from $-1.20 \mathrm{~V}$ toward $\mathrm{E}_{\lambda, a}$, at approximately $-0.94 \mathrm{~V}$ (denoted Peak I), - 0.89 V (Peak II), - 0.72 V (Peak III) and $-0.67 \mathrm{~V}$ (Peak III'), and on reversing the potential, cathodic current peaks were observed at about $-0.96 \mathrm{~V},-1.05 \mathrm{~V}$ and $-1.14 \mathrm{~V}$ [10]. The oxidation and reduction reactions corresponding to these peaks have already been discussed in [10], and the mechanism of passivation is given by Eq. 3:

$$
\begin{aligned}
\mathrm{Fe} & \rightarrow \mathrm{Fe}(\mathrm{OH})_{\text {ads }} \rightarrow \mathrm{Fe}(\mathrm{OH})_{\text {add }}^{+} \rightarrow \mathrm{HFeO}_{2}^{-} \rightarrow \mathrm{Fe}(\mathrm{OH})_{2} \\
& \rightarrow \mathrm{FeOOH} \rightarrow \text { hydrated } \mathrm{FeOOHorFe} \mathrm{O}_{3}
\end{aligned}
$$

As shown from Fig. 1, the current response of mild steel in the anodic and cathodic directions was observed to be significantly different when the electrolyte contained $\mathrm{HS}^{-}$, in comparison with steel immersed in electrolytes without $\mathrm{HS}^{-}$. Similar cyclic voltammograms for steel exposed to alkaline solutions containing sulfide have been observed by Shoesmith et al. [32]. In the presence of $\mathrm{HS}^{-}$in the electrolyte (Fig. 1b and Fig. 1c), the broad anodic current peak, denoted as peaks I and II at $-0.94 \mathrm{~V}$ and $-0.89 \mathrm{~V}$, respectively in Fig. 1a, converted to a doublet. Peak I shifted to lower potentials, approximately $-1.00 \mathrm{~V}$, when the concentration of $\mathrm{HS}^{-}$in the electrolyte was $0.01 \mathrm{M}$; and to an even lower potential $(-1.05 \mathrm{~V})$ when $\left[\mathrm{HS}^{-}\right]$was $0.45 \mathrm{M}$. The position of the peak I did not change upon subsequent anodic sweeps; however, the current density associated with the peak was observed to increase in both electrolytes containing $\mathrm{HS}^{-}$(Fig. 1b and Fig. 1c). Peak II, however, was observed to shift toward more positive potentials with increasing anodic sweeps (centered at $-0.89 \mathrm{~V}$ in the first anodic sweep, and at around $-0.85 \mathrm{~V}$ in the fifth), for electrolytes containing $\mathrm{HS}^{-}$(Fig. $1 \mathrm{~b}$ and Fig. 1c). The current densities associated with peak II in Fig. 1b and Fig. 1c decreased and increased, respectively, upon subsequent anodic sweeps and were observed to be of the same value after the fifth scan in both cases.

With increasing concentration of $\mathrm{HS}^{-}$, the anodic current peaks (Peak III and Peak III') observed at $-0.72 \mathrm{~V}$ and $-0.67 \mathrm{~V}$ were found to decrease in peak current in the case of $0.01 \mathrm{M} \mathrm{HS}^{-}$solutions (Fig. 1b), and completely disappeared in the case of steel immersed in electrolytes containing $0.45 \mathrm{M} \mathrm{HS}^{-}$ (Fig. 1c). Additionally, in alkaline sulfide solutions, an anodic current peak (Peak IV) was observed at $-0.60 \mathrm{~V}$ and $-0.63 \mathrm{~V}$ in Fig. $1 \mathrm{~b}$ and Fig. 1c, respectively. As mentioned in [10], the potential
Table 1 Chemical compositions of electrolytes used to investigate the mechanism of chlorideinduced corrosion in sulfidecontaining alkaline solutions

\begin{tabular}{llllll}
\hline$\left[\mathrm{OH}^{-}\right](\mathrm{M})$ & {$\left[\mathrm{HS}^{-}\right](\mathrm{M})$} & {$\left[\mathrm{HS}^{-}\right](\mathrm{M})$} & {$\left[\mathrm{HS}^{-}\right](\mathrm{M})$} & {$\left[\mathrm{HS}^{-}\right](\mathrm{M})$} & {$\left[\mathrm{Cl}^{-}\right](\mathrm{M})$} \\
\hline 0.80 & 0.001 & 0.01 & 0.09 & 0.45 & 0 to 3.2 \\
1.12 & - & 0.01 & - & 0.45 & 0 to 3.92 \\
1.36 & - & 0.01 & - & 0.45 & 0 to 4.76 \\
\hline
\end{tabular}

Chloride was only added in solutions used for electrochemical measurements 

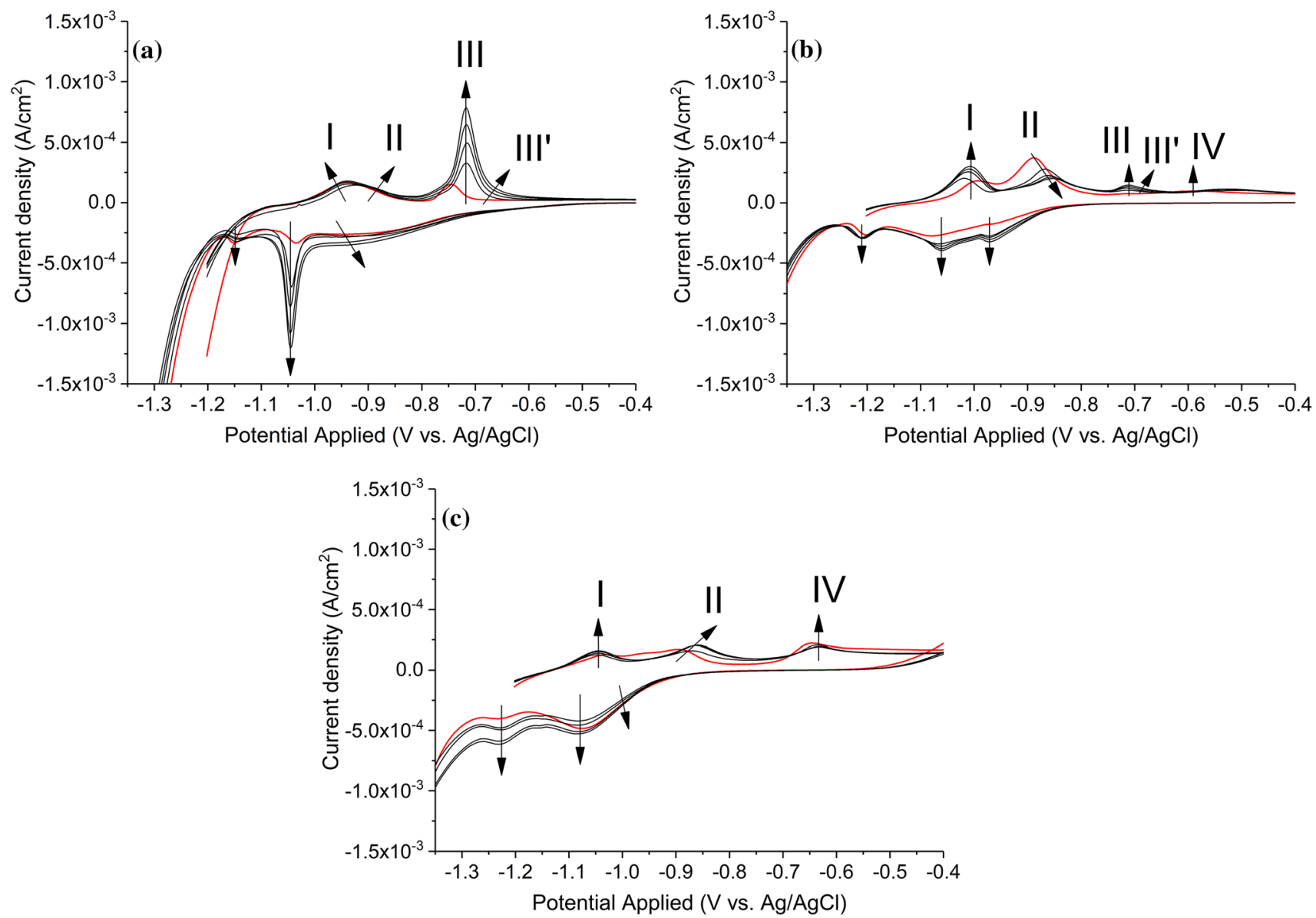

Figure 1 Cyclic voltammograms obtained for mild steel exposed to a $0.80 \mathrm{M} \mathrm{OH}^{-}, \mathbf{b} 0.80227 \mathrm{M} \mathrm{OH}^{-}+0.01 \mathrm{M} \mathrm{HS}-$, and c $0.80 \mathrm{M} \mathrm{OH}^{-}+0.45 \mathrm{M} \mathrm{HS}^{-}$. Data were collected at a sweep rate 228 of $2.5 \mathrm{mV} / \mathrm{s}$. Arrows indicate the current responses in the five scans; each identified response 229 is assigned a Roman numeral for discussion in the text. Data from -1.50 to $-1.20 \mathrm{~V}$ in the 230 anodic sweeps are omitted to enable visibility of all peaks. The red line indicates the first 231 scan, and subsequent scans are represented by black lines. sweep after peak III' (not shown in Fig. 1a) in the anodic direction was characterized by a constant and relatively low anodic current until $0.55 \mathrm{~V}$, at which point a sharp rise in the current was observed due to the evolution of oxygen evolution. In sulfide-containing electrolytes (Fig. $1 \mathrm{~b}$ and c), the current response of the steel-solution interface due to polarization above $-0.40 \mathrm{~V}$ was significantly different from that observed in alkaline solutions without sulfide, and this will be discussed in the following paragraphs in detail.

In the cathodic (or reverse) sweep from $E_{\lambda, a}$ to $E_{\lambda, c}$ the influence of sulfide on the current response (Fig. $1 b$ and c) is much complex than in sulfide-free alkaline solutions (Fig. 1a) and will be addressed in more detail below.
Interpreting anodic response Based on the anodic current response of the mild steel in alkaline solutions containing $0.01 \mathrm{M}$ and $0.45 \mathrm{M} \mathrm{HS}^{-}$, the oxidation reactions occurring at the steel-solution interface can be postulated and the nature of the passive film can be determined. Comparing Fig. $1 \mathrm{~b}$ and $\mathrm{c}$ with Fig. 1a, the disappearance or diminishing of anodic peaks III and III' in the presence of sulfide is evident. As mentioned in [10] and indicated in Eq. 3, peaks III and III' are associated with the formation of $\mathrm{FeOOH}$ due to the oxidation of $\mathrm{Fe}(\mathrm{OH})_{2}$. The lower current density of anodic peaks III and III' in Fig. $1 b$, and their absence from Fig. 1c, suggest that the presence of $\mathrm{HS}^{-}$in alkaline electrolytes inhibits the formation of $\mathrm{FeOOH}, \mathrm{Fe}(\mathrm{OH})_{3}$ or $\mathrm{Fe}_{2} \mathrm{O}_{3} \cdot n \mathrm{H}_{2} \mathrm{O}$ on the surface of the steel, and instead forms a surface layer composed 
of $\mathrm{Fe}^{2+}$ species $[5,32-34]$. It is highly likely that occurrence of peak I at more negative potentials with increasing $\left[\mathrm{HS}^{-}\right]$is due to the competitive adsorption of $\mathrm{OH}^{-}$and $\mathrm{HS}^{-}$species on the steel surface. Shoesmith et al. [32] also concluded that the formation of $\mathrm{Fe}^{2+}$ species instead of $\mathrm{Fe}^{3+}$ oxide species indicate the adsorption of $\mathrm{HS}^{-}$, in addition to $\mathrm{OH}^{-}$, on the steel surface. They also linked this phenomenon to the lower current density during the cathodic sweep at potential values where hydrogen is released from the water [32]. Another possible reason for the shift of peak I to more negative potentials could be the increased ionic strength of the electrolyte [35] with increasing $\left[\mathrm{HS}^{-}\right]$.

In the case of the broad anodic peak II, subsequent anodic sweeps led to a decrease and increase in the current density and the peak potential, respectively, at $0.01 \mathrm{M} \mathrm{HS}^{-}$. However, at $0.45 \mathrm{M} \mathrm{HS}^{-}$, both the current density and the peak potential were observed to increase upon subsequent anodic sweeps. As this peak is observed to form at the same potential of $-0.89 \mathrm{~V}$ in the first anodic scan with $\mathrm{HS}^{-}$(Fig. $1 \mathrm{~b}$ and Fig. 1c) as in sulfide free electrolytes (Fig. 1a), it is identified as showing the formation of $\mathrm{Fe}(\mathrm{OH})_{2}$ species on the steel surface. Additionally, the stabilization of the peak current and the peak potential to very similar values after the fifth scan in both Fig. $1 \mathrm{~b}$ and Fig. 1c suggests that peak II is only related to the $\mathrm{OH}^{-}$species in the electrolyte.

Therefore, similar to the reaction route observed in sulfide-free solutions described in [10], peaks I and II in the case of sulfide-containing alkaline solutions can possibly be described by Eqs. 4-9:

$$
\begin{aligned}
& \mathrm{Fe}+\mathrm{OH}^{-} \leftrightarrow[\mathrm{Fe}(\mathrm{OH})]_{\mathrm{ads}}+e^{-} \\
& {[\mathrm{Fe}(\mathrm{OH})]_{a d s} \leftrightarrow[\mathrm{Fe}(\mathrm{OH})]_{\mathrm{ads}}^{+}+e^{-}} \\
& \mathrm{Fe}+\mathrm{HS}^{-} \leftrightarrow[\mathrm{Fe}(\mathrm{HS})]_{\mathrm{ads}}+e^{-} \\
& {[\mathrm{Fe}(\mathrm{HS})]_{\mathrm{ads}} \leftrightarrow[\mathrm{Fe}(\mathrm{HS})]_{\mathrm{ads}}^{+}+e^{-}} \\
& {[\mathrm{Fe}(\mathrm{OH})]_{\mathrm{ads}}^{+}+2 \mathrm{OH} \leftrightarrow \leftrightarrow \mathrm{HFeO}_{2}^{-}+\mathrm{H}_{2} \mathrm{O}} \\
& \mathrm{HFeO}_{2}^{-}+\mathrm{H}_{2} \mathrm{O} \leftrightarrow\left\{\mathrm{Fe}(\mathrm{OH})_{2}\right\}+\mathrm{OH}^{-}
\end{aligned}
$$

The reactions occurring at peak I can be described by the competitive adsorption of $\mathrm{OH}^{-}$and $\mathrm{HS}^{-}$on the steel surface forming an adsorbed layer of $\mathrm{Fe}[\mathrm{OH}]^{+}{ }_{\text {ads }}$ and $\mathrm{Fe}[\mathrm{HS}]^{+}$ads due to a double electron transfer process. The relative amounts of $\mathrm{Fe}[\mathrm{HS}]^{+}$ads and $\mathrm{Fe}[\mathrm{OH}]^{+}$ads adsorbed on the surface are dependent on the concentration of $\mathrm{HS}^{-}$in the electrolyte solution, with more $\mathrm{Fe}[\mathrm{HS}]^{+}$ads adsorbing on the surface at higher sulfide concentration [5, 32]. This is also confirmed by the current density in peak I observed for cyclic voltammograms obtained for electrolytes with $1.12 \mathrm{M} \mathrm{OH}^{-}+0.01 \mathrm{M} \mathrm{HS}^{-}$, and $1.36 \mathrm{M} \mathrm{OH}^{-}$and $0.01 \mathrm{M} \mathrm{HS}^{-}$(Figure S2, Supplementary Information). As mentioned in [10], peak II is primarily related to the $\left[\mathrm{OH}^{-}\right]$in the electrolyte, and therefore can be attributed to adsorbed $\mathrm{Fe}[\mathrm{OH}]_{\text {ads }}^{+}$species converting to $\mathrm{Fe}(\mathrm{OH})_{2}$ (as indicated by Eqs. 8-9) in the presence or absence of $\mathrm{HS}^{-}$ (Fig. $1 \mathrm{a}, \mathrm{b}$ and $\mathrm{c}$ ).

There has been debate in the literature about the designation of peaks I and II; several authors have indicated that peaks I and II correspond to the formation of $\mathrm{Fe}(\mathrm{OH})_{2}$ and $\mathrm{Fe}_{3} \mathrm{O}_{4}$, respectively $[5,32,33,36,37]$. However, as shown in Fig. $1 b$ and c, the current density of peak I depends on the concentration of $\mathrm{HS}^{-}$(and also on $\left[\mathrm{OH}^{-}\right]$, for a given concentration of $\mathrm{HS}^{-}$), whereas the current density at peak II depends on $\left[\mathrm{OH}^{-}\right]$but is independent of $\left[\mathrm{HS}^{-}\right]$upon subsequent anodic sweeps. Therefore, it is reasonable to identify that peak I corresponds to the competitive adsorption of $\mathrm{HS}^{-}$and $\mathrm{OH}^{-}$on the steel surface, and peak II corresponds to the formation of $\mathrm{Fe}(\mathrm{OH})_{2}$ via $\mathrm{HFeO}_{2}{ }^{-}$. It is unlikely that at such high alkalinity, the dehydroxylation of $\mathrm{Fe}(\mathrm{OH})_{2}$ to yield $\mathrm{Fe}_{3} \mathrm{O}_{4}$ would occur.

The anodic peaks III and III' diminish and disappear with increasing $\mathrm{HS}^{-}$in the electrolyte due to the highly reducing nature of $\mathrm{HS}^{-}$. In the case of alkaline solutions without $\mathrm{HS}^{-}$(Fig. 1a), peak III is associated with the formation of $\mathrm{FeOOH}$ and peak III' is associated with the hydration of $\mathrm{FeOOH}$ to $\mathrm{Fe}(\mathrm{OH})_{3}$, or the formation of hydrous $\mathrm{Fe}_{2} \mathrm{O}_{3} \cdot n \mathrm{H}_{2} \mathrm{O}$, and the amount of $\mathrm{Fe}^{3+}$ species formed increases with increasing $\left[\mathrm{OH}^{-}\right][10]$. In the case of electrolytes containing $0.01 \mathrm{M} \mathrm{HS}^{-}$(Fig. 1b), a smaller current density is recorded at $-0.72 \mathrm{~V}$ and $-0.67 \mathrm{~V}$ when compared to Fig. 1a, and like sulfide-free electrolytes, the current density of peaks III and III' in electrolytes with $0.01 \mathrm{M} \mathrm{HS}^{-}$was observed to increase with increasing $\left[\mathrm{OH}^{-}\right]$in the solution (Figure S2, Supplementary Information). Therefore, peaks III and III' in Fig. $1 \mathrm{~b}$ can be collectively described by Eqs. 10-12:

$$
\begin{aligned}
& \left\{\mathrm{Fe}(\mathrm{OH})_{2}\right\}+\mathrm{OH}^{-} \leftrightarrow[\mathrm{FeOOH}]_{\mathrm{ads}}+\mathrm{H}_{2} \mathrm{O}+e^{-} \\
& 2[\mathrm{FeOOH}]_{\mathrm{ads}} \leftrightarrow\left\{\mathrm{Fe}_{2} \mathrm{O}_{3} \cdot \mathrm{H}_{2} \mathrm{O}\right\}
\end{aligned}
$$




$$
[\mathrm{FeOOH}]_{\mathrm{ads}}+\mathrm{H}_{2} \mathrm{O} \leftrightarrow\left\{\mathrm{FeOOH} \cdot \mathrm{H}_{2} \mathrm{O}\right\}
$$

In the case of the relatively broad anodic current peak IV observed in Fig. $1 \mathrm{~b}$ and Fig. 1c, the current density is observed to increase with increasing [HS ${ }^{-}$] in the electrolyte, however did not change with the alkalinity of the electrolyte (Figure S2, Supplementary Information), indicating that its occurrence was related to the $\mathrm{HS}^{-}$in the electrolyte. This peak could possibly be related to the formation of an Fe-S complex on the steel surface and the following reaction route (Eq. 13, 14) is proposed [5, 32]:

$$
\begin{aligned}
& {[\mathrm{Fe}(\mathrm{HS})]_{\text {ads }}^{+}+\mathrm{HS}^{-} \leftrightarrow\left\{\mathrm{Fe}(\mathrm{HS})_{2 \mathrm{ads}}\right\}} \\
& \mathrm{Fe}(\mathrm{HS})_{2 \mathrm{ads}}+\mathrm{OH}^{-} \leftrightarrow\{\mathrm{Fe}-\text { Scomplex }\}+\mathrm{H}_{2} \mathrm{O}+e^{-}
\end{aligned}
$$

Under this mechanism, the adsorbed $\mathrm{Fe}[\mathrm{HS}]^{+}$ads reacts with the $\mathrm{HS}^{-}$in the electrolyte to form an adsorbed layer of $\mathrm{Fe}[\mathrm{HS}]_{2}$ [32], which then reacts with the $\mathrm{OH}^{-}$in the electrolyte resulting in an $\mathrm{Fe}-\mathrm{S}$ complex [5] that can then transform upon polarization.

This interpretation differs significantly from mechanisms proposed in previous literature. Tromans [38] suggested that the surface film formed on mild steel in hot alkaline solutions containing sulfide was composed of complex $\gamma-\mathrm{Fe}_{3} \mathrm{O}_{4}$ with some sulfide substitution for oxygen $\left(\gamma-\mathrm{Fe}_{3} \mathrm{O}_{4-x} \mathrm{~S}_{x}\right)$. Conversely, Shoesmith et al. [32] proposed the formation of an iron oxide film (attributed to peak I in their study), irrespective of the concentration of $\mathrm{HS}^{-}$in the electrolyte, and attributed peak IV to the oxidation of $\mathrm{HS}^{-}$to deposited elemental sulfur, following a hypothesis posed in the earlier literature [39]. Shoesmith et al. [32] also claimed that the growth of iron sulfide (mackinawite) species occurs at more anodic potentials than peak IV, and at defect sites in the iron oxide film formed, leading to pitting corrosion $[32,40]$. However, the oxidation of $\mathrm{HS}^{-}$to elemental $\mathrm{S}$ involves the release of $\mathrm{H}^{+}$, which would decrease the $\mathrm{pH}$ of the electrolyte. In the current study, the $\mathrm{pH}$ of the electrolyte before and after the occurrence of peak IV was constant at 13.85 (as shown in Figure S3, Supplementary Information), with no acidification observed, and therefore this sulfur deposition mechanism at potentials close to peak IV $(\sim-0.60 \mathrm{~V})$ appears highly unlikely. Additionally, the imposed potential required to deposit elemental sulfur from the aqueous solution on the surface of the steel was observed much higher than $-0.60 \mathrm{~V}$ (as shown in Fig 2) and has been discussed in greater detail in "Interpreting cathodic responses" section. Therefore, in the case of electrolyte containing $0.01 \mathrm{M} \mathrm{HS}^{-}$, the identification that peak IV represents the formation of a Fe-S complex on an $\mathrm{FeOOH}$ film is supported.

At $0.45 \mathrm{M} \mathrm{HS}^{-}$, peak IV indicates that the surface of the steel is essentially an Fe-S complex on a relatively less stable $\mathrm{Fe}(\mathrm{OH})_{2}$ film, and the oxidation of $\mathrm{Fe}$ to the +3 state is not possible. Upon increasing [HS ${ }^{-}$] from 0.01 to $0.45 \mathrm{M}$, the anodic peak IV was observed at a lower potential $(-0.63 \mathrm{~V}$ in Fig. 1c, cf. $-0.60 \mathrm{~V}$ in Fig. 1b) due to the higher availability of $\mathrm{HS}^{-}$at the steel-solution interface and the much higher polarizability of the $\mathrm{HS}^{-}$than $\mathrm{OH}^{-}$, displacing $\mathrm{OH}^{-}$from the steel-solution interface. A similar shift has been observed by Shoesmith et al. [32] when testing an electrolyte with $0.50 \mathrm{M} \mathrm{HS}^{-}$.

Interpreting cathodic responses For the data presented in Fig. $1 b$ and c, i.e., the current response of the system for potentials lower than $-0.4 \mathrm{~V}$, three reduction peaks can be observed. In the case of solutions with $0.01 \mathrm{M} \mathrm{HS}^{-}$(Fig. 1b), two broad reduction peaks are observed at approximately $-0.97 \mathrm{~V}$ and $-1.06 \mathrm{~V}$, and a distinct peak is observed at approximately - 1.21 V. Upon subsequent cathodic sweeps, the broad peaks centered at $-0.97 \mathrm{~V}$ and $-1.06 \mathrm{~V}$ become more distinct. When the concentration of $\mathrm{HS}^{-}$is increased to $0.45 \mathrm{M}$ (Fig. 1c), the cathodic sweep is characterized by three broad overlapping peaks centered at approximately $-0.99 \mathrm{~V},-1.08 \mathrm{~V}$ and $-1.23 \mathrm{~V}$. The current density in the cathodic sweep at potentials $<-1.25 \mathrm{~V}$ is much lower in the presence of sulfide, suggesting a depressed release of hydrogen due to the breakdown of water. However, prior to attributing the cathodic peaks to specific reduction reactions, it is necessary to understand the anodic response of the steel-solution interface at potentials $>-0.40 \mathrm{~V}$ in sulfide-containing solutions.

To this end, Fig 2 shows only the first cycle of the cyclic voltammetry scans for mild steel exposed to solutions of: (A) $0.80 \mathrm{M} \mathrm{OH}^{-}$, (B) $0.80 \mathrm{M} \mathrm{OH}^{--}$ $+0.01 \mathrm{M} \mathrm{HS}^{-}$, and (C) $0.80 \mathrm{M} \mathrm{OH}+0.45 \mathrm{M} \mathrm{HS}^{-}$. For the purpose of visibility, data from $\mathrm{E}_{\lambda, c}(-1.50 \mathrm{~V}$ vs. $\mathrm{Ag} / \mathrm{AgCl})$ to $-1.20 \mathrm{~V}$ are not shown. One of the major differences evident between Fig $2 a, b$ and $c$, is the current response of the steel-solution interface at potentials $>-0.40 \mathrm{~V}$ : at potentials between -0.40 

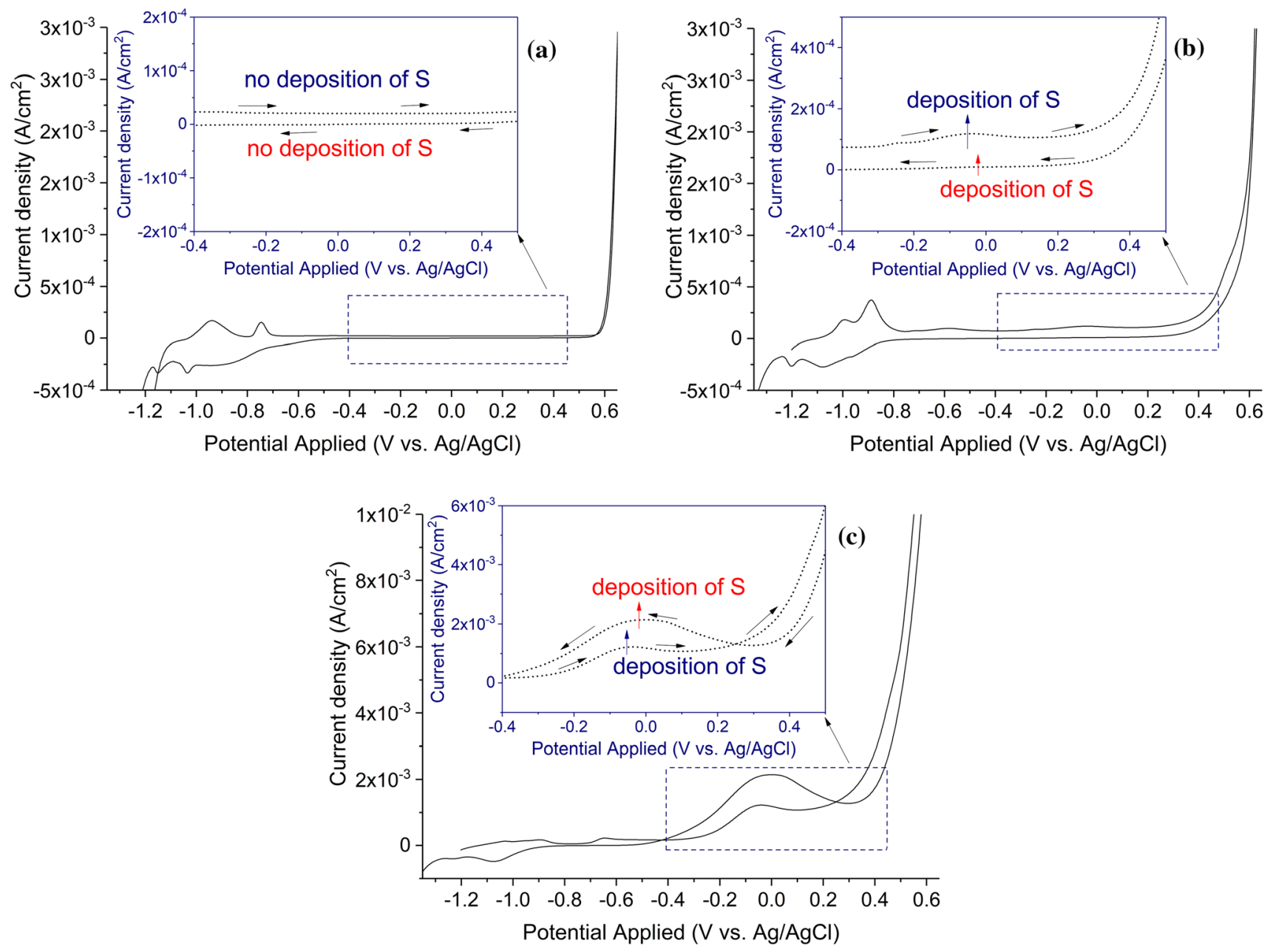

Figure 2 First scan obtained for each sample during the cyclic voltammetry measurements, for mild steel exposed to a $0.80 \mathrm{M}$ $\mathrm{OH}^{-}, \quad$ b $\quad 0.80 \mathrm{M} \mathrm{OH}^{-}+0.01 \mathrm{M} \mathrm{HS}^{-}$and c $0.80 \mathrm{M}$

and $-0.35 \mathrm{~V}$, the anodic current density is much higher for solutions with a higher $\left[\mathrm{HS}^{-}\right]$, indicating a lower extent of passivation in sulfide-containing solutions. The anodic sweep from $-0.35 \mathrm{~V}$ toward $\mathrm{E}_{\lambda, a}$ in Fig. 2b, c is characterized by a broad peak centered at potentials close to $\sim-0.05 \mathrm{~V}$ and $\mathrm{a}$ sharp rise in the current density at $\sim 0.30 \mathrm{~V}$, occurring as a shoulder at $\sim 0.45 \mathrm{~V}$, with the anodic peak typical of oxygen evolution at $0.55 \mathrm{~V}$. The absence of these peaks in Fig. 2a, where the electrolyte did not contain any $\mathrm{HS}^{-}$, indicates that they are primarily related to the presence of $\mathrm{HS}^{-}$in the electrolyte solution. The anodic peak at $-0.05 \mathrm{~V}$ and the subsequent shoulder at $0.45 \mathrm{~V}$ are therefore associated with the oxidation of dissolved $\mathrm{HS}^{-}$in the electrolyte.
$\mathrm{OH}^{-}+0.45 \mathrm{M} \mathrm{HS}{ }^{-}$, highlighting the oxidation reactions associated with anodic peaks at $-0.05 \mathrm{~V}$ and $0.45 \mathrm{~V}$.

Based on Fig. 2b, c, several oxidation reactions could be proposed to be associated with the anodic peaks at $-0.05 \mathrm{~V}$ and $0.45 \mathrm{~V}$, and a plausible reaction route can be described (Eq. 15-19) [32, 41, 42]:

$$
\begin{aligned}
& x \mathrm{HS}^{-} \leftrightarrow \mathrm{S}_{x}^{2-}+x \mathrm{H}^{+}+(2 x-2) e^{-} \quad 2<x<5 \\
& \mathrm{~S}_{x}^{2-}+6 \mathrm{OH}^{-} \rightarrow \mathrm{SO}_{3}^{2-}+(x-1) \mathrm{S}^{0}+3 \mathrm{H}_{2} \mathrm{O}+6 e^{-} \\
& \mathrm{SO}_{3}^{2-}+\mathrm{OH}^{-} \leftrightarrow \mathrm{HS}^{-}=\mathrm{S}_{2} \mathrm{O}_{3}^{2-}+\mathrm{H}_{2} \mathrm{O}+2 e^{-} \\
& \mathrm{SO}_{3}^{2-}+\mathrm{OH}^{-} \leftrightarrow \mathrm{SO}_{4}^{2-}+2 e^{-}+\mathrm{H}^{+} \\
& \mathrm{S}_{2} \mathrm{O}_{3}^{2-}+\mathrm{OH}^{-}+\mathrm{HS}^{-} \leftrightarrow \mathrm{SO}_{4}^{2-}+\mathrm{H}_{2} \mathrm{~S}+2 e^{-}
\end{aligned}
$$

The $\mathrm{pH}$ of the bulk solution dropped significantly from 13.85 to 12.97 when moving in the anodic direction (as shown in Figure S3, Supplementary 
Information) from $-0.35 \mathrm{~V}$ toward $\mathrm{E}_{\lambda, a}$, possibly due to the formation of hydrogen ions during the occurrence of anodic current peaks at $-0.05 \mathrm{~V}$ and $0.45 \mathrm{~V}$ (Eq. 15) [32, 43]. The release of $\mathrm{H}^{+}$ions during the oxidation of $\mathrm{HS}^{-}$(Eq. 15) in the electrolyte at the steel-solution interface may possibly lead to the breakdown of the surface film formed due to the oxidation reactions shown in Eqs. 4, 5, 6, 7, 8, 9, 10, 11, $12,13,14$.

The polysulfide ions formed in the system are oxidized to $\mathrm{SO}_{3}{ }^{2-}$ and elemental S (Eq. 16) [44, 45]. Shoesmith et al. [32] showed that the variation in current density and the potential of the anodic peak in their experiments were consistent with the deposition of an elemental sulfur film [46], and the results presented here are consistent with that argument. In alkaline solutions, Avrahami and Golding [45] observed that the oxidation of $\mathrm{SO}_{3}{ }^{2-}$ to either thiosulfate $\left(\mathrm{S}_{2} \mathrm{O}_{3}{ }^{2-}\right)$ (Eq. 17) or sulfate $\left(\mathrm{SO}_{4}{ }^{2-}\right)(\mathrm{Eq} .18)$ is almost instantaneous, and the therefore, the rate determining step is the oxidation of $\mathrm{HS}^{-}$to $\mathrm{SO}_{3}{ }^{2-}$. Subsequent oxidation of $\mathrm{S}_{2} \mathrm{O}_{3}{ }^{2-}$ to $\mathrm{SO}_{4}{ }^{2-}$, as described by Eq. 19, could also occur at potentials prior to oxygen evolution and would be characterized by the evolution of $\mathrm{H}_{2} \mathrm{~S}$. Equation 19 is primarily proposed due to observation of a foul odor (due to the evolution of $\mathrm{H}_{2} \mathrm{~S}$ ), particularly when the potential was increased from 0.40 to $0.6 \mathrm{~V}$.

Another major difference between the cyclic voltammograms of steel immersed in sulfide-containing (Fig. 2b, c) and in sulfide-free solutions (Fig. 2a) is the current density associated with the evolution of oxygen at $0.55 \mathrm{~V}$. The current density observed due to oxygen evolution is significantly higher in the presence of sulfide. This is attributed to oxidation of reduced sulfur species at the steel-solution interface, and the removal of any deposited elemental $\mathrm{S}$ on the surface of the steel during the evolution of oxygen.

In sulfide-containing solutions (Fig. $2 b, c$ ), the cathodic sweep from $\mathrm{E}_{\lambda, a}$ toward $\mathrm{E}_{\lambda, c}$ is characterized by an unusual current density peak at $-0.02 \mathrm{~V}$ representing an oxidation reaction rather than the usual reduction reactions seen during the cathodic sweep (as seen in [10] and in Fig. 2a). This unusual oxidation peak is probably due to the oxidation of $\mathrm{HS}^{-}$at the steel-solution interface as well as in the bulk solution. As shown from Fig. $2 b$ and Fig. $2 c$, this peak is influenced by the concentration of $\mathrm{HS}^{-}$in the electrolyte. In addition, the $\mathrm{pH}$ of the bulk solution measured after the occurrence of this peak (particularly in Fig. 2c) is around 12.4 (much lower than that observed during the anodic sweep), indicating the release of $\mathrm{H}^{+}$ions. Therefore, in the case of Fig. 2c, the electrolyte solution is altered during the reverse cathodic sweep, and the cathodic current peaks observed in Fig. 1c cannot be directly attributed to the reversal of the oxidation reactions in Eqs. 4-14. However, for electrolytes containing $0.01 \mathrm{M} \mathrm{HS}^{-}$ (Fig. 2b, and Fig. 1b), the current density of the unusual peak at $-0.02 \mathrm{~V}$ is almost zero, and the cathodic peaks do represent the reversal of the anodic processes. The cathodic peak observed in Fig. $1 \mathrm{~b}$ centered at $-1.21 \mathrm{~V}$ corresponds to the reduction of the species formed in peak $\mathrm{I}(-1.00 \mathrm{~V})$, the reduction peak at $-1.06 \mathrm{~V}$ corresponds to the reduction in the species formed in peaks II, III and III' $(-0.89 \mathrm{~V}$, $-0.72 \mathrm{~V}$, and $-0.67 \mathrm{~V}$ ), and the broad cathodic peak at $-0.97 \mathrm{~V}$ corresponds to the anodic product formed at $-0.60 \mathrm{~V}$.

Based on the above discussion, it is important to highlight that for sulfide-containing electrolytes and particularly those representing the pore solution of AAS, the original composition of the steel surface can only be determined using the anodic response of the first scan in a cyclic voltammetry test, as the chemistry of the electrolyte solution is altered significantly during the reverse cathodic sweep. Therefore, for steel immersed in simulated pore solutions representative of AAS, the high concentration of $\mathrm{HS}^{-}$in the pore solution clearly alters the chemistry of the surface film, which in this case is primarily composed of $\mathrm{Fe}^{2+}$ species, with the inner layer being $\mathrm{Fe}(\mathrm{OH})_{2}$ and the outer layer being an Fe-S complex. It is equally important to note that the oxidation mechanism, under an applied potential, responsible for the conversion of sulfide from the aqueous solution to elemental sulfur and its deposition on the surface of the steel occurs through an irreversible reaction at approximately $-0.05 \mathrm{~V}$ versus $\mathrm{Ag} / \mathrm{AgCl}$, which is much higher than the open circuit potential of the steel (as shown in "Open circuit potential and linear polarization resistance" section).

Open-circuit potential and linear polarization resistance

Figure $3 a, b$ shows the influence of varying concentrations of $\mathrm{HS}^{-}$on the evolution of the OCP and polarization resistance $\left(R_{p}\right)$, obtained using LPR tests method as described in "Passivation" section, of mild 
steel immersed in an alkaline solution over 28 days, respectively. With an increase in $\left[\mathrm{HS}^{-}\right]$, both $\mathrm{OCP}$ and $R_{p}$ were observed to decrease. In the sulfide-free solution $(0.80 \mathrm{M} \mathrm{NaOH})$, the OCP increased from an initial -0.32 to $-0.12 \mathrm{~V}$ after 12 days, remaining stable at this value. The addition of a very low concentration of $\mathrm{HS}^{-}(0.001 \mathrm{M})$ gave similar behavior but with stabilization at $\sim-0.22 \mathrm{~V}$ after 12 days. This very low $\mathrm{HS}^{-}$concentration appears not to change
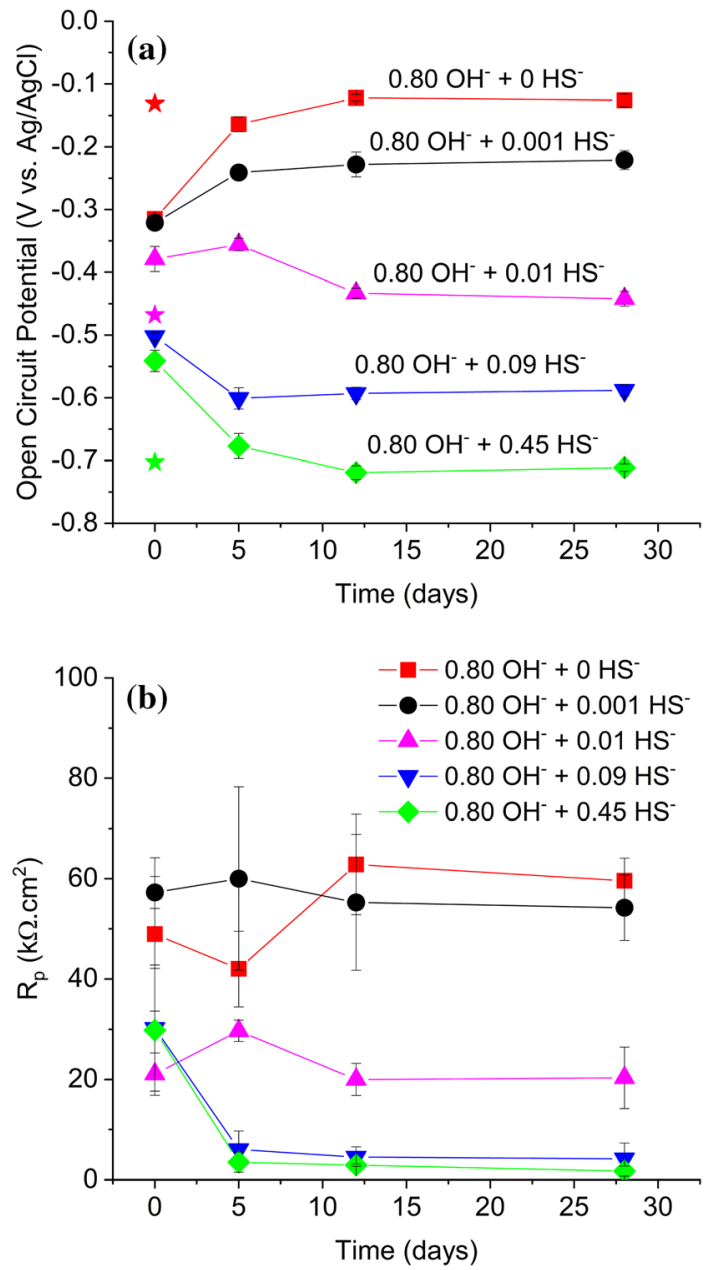

Figure 3 Evolution of the $\mathbf{a}$ OCP and $\mathbf{b}$ polarization resistance $\left(R_{p}\right)$ values determined using the LPR test, for steel immersed in $0.80 \mathrm{M} \mathrm{NaOH}$ with varying concentrations of $\mathrm{HS}^{-}$as marked, and error bars indicating the results of replicate measurements. The $\mathrm{pH}$ values corresponding to these data points are reported in Table S1, Supplementary Information. The data points indicated in (A) by the star symbol refer to the OCP of an inert iridium electrode (experimental details in Supplementary Information Sect. 5) exposed to $0.80 \mathrm{M} \mathrm{OH}^{-}$(red star), $0.80 \mathrm{M} \mathrm{OH}^{-}+0.01 \mathrm{M}$ $\mathrm{HS}^{-}$(magenta star), and $0.80 \mathrm{M} \mathrm{OH}^{-}+0.45 \mathrm{M} \mathrm{HS}^{-}$(green star). the passive film chemistry to a significant extent from the sulfide-free case as described in "Cyclic voltammetry" section. In these alkaline solutions, with zero and $0.001 \mathrm{M} \mathrm{HS}^{-}$, the polarization resistance was relatively stable between 45 and $60 \mathrm{k} \Omega \mathrm{cm}^{2}$ (Fig. 3b). In the case of steel immersed in solutions containing intermediate $(0.01 \mathrm{M}$ and $0.09 \mathrm{M})$ and high $(0.45 \mathrm{M})$ concentrations of $\mathrm{HS}^{-}$, the OCP was $<-0.40 \mathrm{~V}$ (Fig. 3a). Similarly, measured $R_{p}$ values were observed to be significantly lower (Fig. 3b). In both PC-slag blends [14, 18, 47] and alkali-activated fly ash/slag blends [26, 48], an increase in the amount of total reduced sulfur in the pore solution brings a significant decrease in the amount of dissolved oxygen in the electrolyte [14] and in the OCP of the steel reinforcement. The reducing nature (or a reduction in the dissolved oxygen content) of sulfide-containing solutions has been confirmed by OCP measurements of an inert iridium electrode (shown in Fig. 3a and discussed in Sect. 5, Supplementary Information). The observations in simulated pore solutions here (Fig. 3a) are able to replicate this trend; in the case designed to represent the pore solution of AAS $\left(0.80 \mathrm{M} \mathrm{OH}^{-}+0.45 \mathrm{M} \mathrm{HS}^{-}\right)$, the measured OCP of $-0.71 \mathrm{~V}$ was very similar to values obtained by analysis of steel embedded in AAS mortars [27, 49, 50].

As shown in Fig. 3b, the polarization resistance for mild steel in alkaline solutions decreases with an increase in the concentration of $\mathrm{HS}^{-}$in the electrolyte, which is consistent with literature data for steel embedded in mortars with different binder types [49]. On this basis, using the modified Stern-Geary equation and using a proportionality constant $B$ value of $52 \mathrm{mV}$ for steel in the passive state [51], the corrosion current density ( $\left.i_{\text {corr }}\right)$ would be expected to increase with increasing [HS ${ }^{-}$[ [14]. The observation of a lower $R_{p}$ and higher current density for mild steel in sulfide-containing alkaline solutions is also in line with the cyclic voltammetry results described in "Cyclic voltammetry" section. However, the reason for such low $R_{p}$ values in solutions with high [HS ${ }^{-}$] could also be related to the aqueous chemistry of the electrolyte, and this will be revisited in detail below.

\section{Anodic polarization}

Figure 4 shows the influence of sulfide in alkaline solutions on the anodic behavior of mild steel. As shown in [10], the anodic polarization of mild steel in 
highly alkaline solutions without sulfide is characterized by a clear transition from the active to the passive and the trans-passive regions (denoted by the red line in Fig. 4). The results for $0.001 \mathrm{M} \mathrm{HS}^{-}$again follow the same trend as the sulfide-free case. With increasing $\left[\mathrm{HS}^{-}\right]$, a clear reduction in the OCP and a significant increase in the current density is shown in Fig. 4, in agreement with the findings from Fig. 3a, $\mathrm{b}$ as discussed above. For solutions where $\left[\mathrm{HS}^{-}\right]-$ $\geq 0.01 \mathrm{M}$, the active and the passive regions are not readily identifiable; instead, the polarization of steel in the anodic direction ( $>$ OCP) resulted in a sharp rise in the current density until an anodic peak was observed around $-0.05 \mathrm{~V}$. Similar anodic polarization curves characterized by high current densities were observed by Tromans [38] for steel immersed in hot alkaline sulfide solutions but no direct passivation was seen. The presence of the anodic peak at $\sim-0.05 \mathrm{~V}$ and a subsequent drop in the current density at potentials $>-0.05 \mathrm{~V}$ can be taken to confirm the deposition of $\mathrm{S}$ through the reaction pathway described in Eq. 15 and Eq. 16, as discussed above.

The formation of a passive film and/or corrosion products depends on the kinetics of both the anodic and cathodic half-cell reactions. In the case of steel in alkaline solutions without sulfide (red line in Fig. 4), the anodic polarization of the steel specimen leads to the anodic dissolution of $\mathrm{Fe}$, forming $\mathrm{Fe}^{2+}$, when the potential is increased from the OCP to approximately

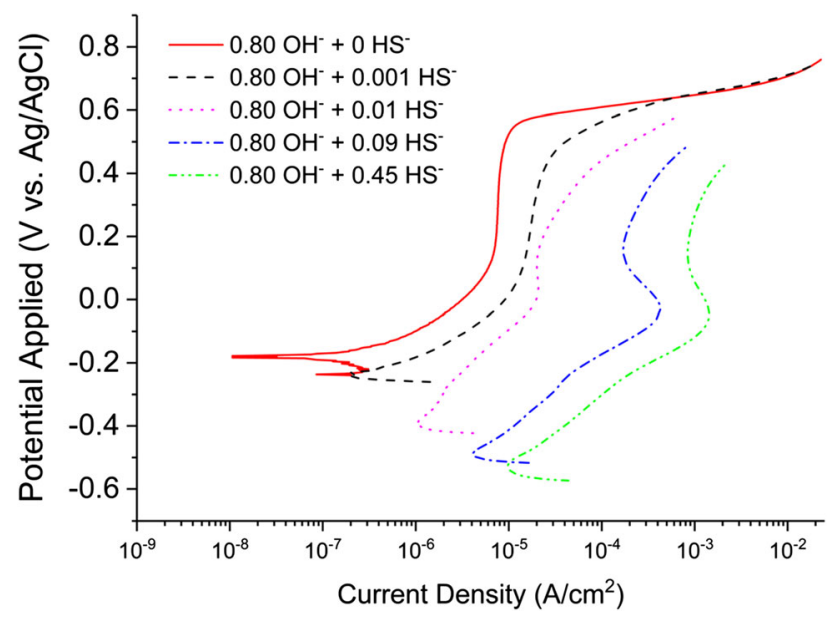

Figure 4 Influence of sulfide (concentrations as marked) on the anodic polarization behavior of obtained mild steel immersed in $0.80 \mathrm{M} \mathrm{NaOH}$.
$0.15 \mathrm{~V}$ (active region), and a region of constant current density indicative of the formation of an $\mathrm{Fe}^{3+}$ passive film between 0.15 and $0.55 \mathrm{~V}$. The strong similarities between the anodic polarization of steel in solutions containing $\left[\mathrm{HS}^{-}\right] \geq 0.01 \mathrm{M}$ and the current response in the anodic sweep of the first cyclic voltammetry scans (Fig. 2) at potentials $>-0.6 \mathrm{~V}$ indicate that the increase in current density in Fig. 4 at potentials above the OCP is primarily due to the oxidation of $\mathrm{HS}^{-}$species within the electrolyte. This has been confirmed by anodic polarization tests done on an inert iridium electrode in $0.80 \mathrm{M} \mathrm{NaOH}$ solutions with and without sulfide $(0 \mathrm{M}, 0.01 \mathrm{M}$ and $0.45 \mathrm{M} \mathrm{HS}^{-}$)—shown in Sect. 5, Supplementary Information. Thus, the anode in these electrochemical systems is identified as being the dissolved $\mathrm{HS}^{-}$that can readily oxidize under an applied potential, rather than Fe. This therefore explains the absence of $\mathrm{Fe}$ dissolution features in the anodic polarization curves. The fact that HS $^{-}$is the anode in these electrochemical systems is significant when considering the formation of a macro-cell to initiate chloride-induced corrosion of the steel reinforcement in concrete and is addressed in detail below.

\section{X-ray photoelectron spectroscopy}

Figure 5 and Figures S4 and S5 (in Supplementary Information) show deconvoluted $S 2 p$ and $\mathrm{Fe} 2 p_{3 / 2}$ XPS spectra for the steel surfaces exposed to solutions containing $0.80 \mathrm{M} \mathrm{NaOH}$ and varying sulfide concentrations, for 5,12 and 28 days, respectively. When steel is exposed to solutions containing $0.80 \mathrm{M}$ $\mathrm{OH}^{-}+0.01 \mathrm{M} \mathrm{HS}^{-}$for 5 days (Fig. 5a), the $\mathrm{S}$ $2 p$ spectra is characterized by $\mathrm{S} 2 p_{3 / 2}$ peaks representing $\mathrm{Fe}^{2+} \mathrm{S}, \mathrm{Fe}^{2+} \mathrm{S} / \mathrm{Fe}^{2+} \mathrm{S}_{n}, \mathrm{FeSO}_{3}$ and $\mathrm{FeS}_{2} \mathrm{O}_{3}$ centered at $160.98 \mathrm{eV}, 162 \mathrm{eV}, 164.6 \mathrm{eV}$ and $166.4 \mathrm{eV}$, respectively [8, 30, 52-54]. However, at higher $\left[\mathrm{HS}^{-}\right]$ (Fig. $5 c$, e), the S $2 p$ spectra exhibit only the $160.98 \mathrm{eV}$ and $162 \mathrm{eV}$ peaks, indicating the presence of only $\mathrm{Fe}^{2+} \mathrm{S}$ and $\mathrm{Fe}^{2+} \mathrm{S} / \mathrm{Fe}^{2+} \mathrm{S}_{n}$ species on the surface of the steel $[8,30,52-54]$. As the high $\mathrm{HS}^{-}$concentration creates a highly reducing environment around the steel surface (Fig. 3) and due to the extremely low amount of dissolved oxygen at the steel-solution interface [14], oxidized sulfur species are not observed. Comparing the intensities of the $S 2 p_{3 / 2}$ peaks associated with $\mathrm{Fe}^{2+} \mathrm{S}$ and $\mathrm{Fe}^{2+} \mathrm{S} / \mathrm{Fe}^{2+} \mathrm{S}_{n}$ in Fig 5 a, c, e, it is clear that the formation of $\mathrm{Fe}^{2+} \mathrm{S}$ is preferred at higher $\left[\mathrm{HS}^{-}\right]$, consistent with the 
Figure $5 \mathrm{~S} 2 p$ and $\mathrm{Fe} 2 p_{3 / 2}$ XPS spectra of steel specimens exposed to alkaline sulfide solutions for 5 days. a and b show the $\mathrm{S} 2 p$ and $\mathrm{Fe} 2 p_{3 / 2}$ spectra, respectively, for steel immersed in $0.80 \mathrm{M}$ $\mathrm{OH}^{-}+0.01 \mathrm{M} \mathrm{HS}^{-} ; \mathbf{c}$ and d show the $\mathrm{S} 2 p$ and $\mathrm{Fe} 2 p_{3 / 2}$ spectra, respectively, for steel immersed in $0.80 \mathrm{M}$ $\mathrm{OH}^{-}+0.09 \mathrm{M} \mathrm{HS}^{-}$; and e and $\mathbf{f}$ show the $\mathrm{S} 2 p$ and $\mathrm{Fe}$ $2 p_{3 / 2}$ spectra, respectively, for steel immersed in $0.80 \mathrm{M}$ $\mathrm{OH}^{-}+0.45 \mathrm{M} \mathrm{HS}^{-}$. (a)

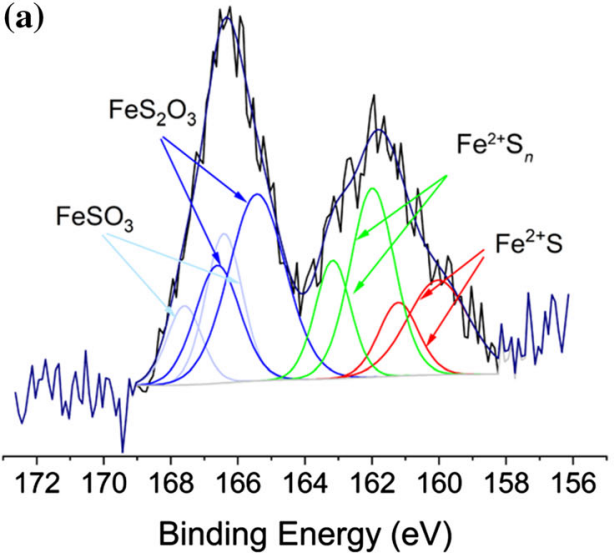

(c)

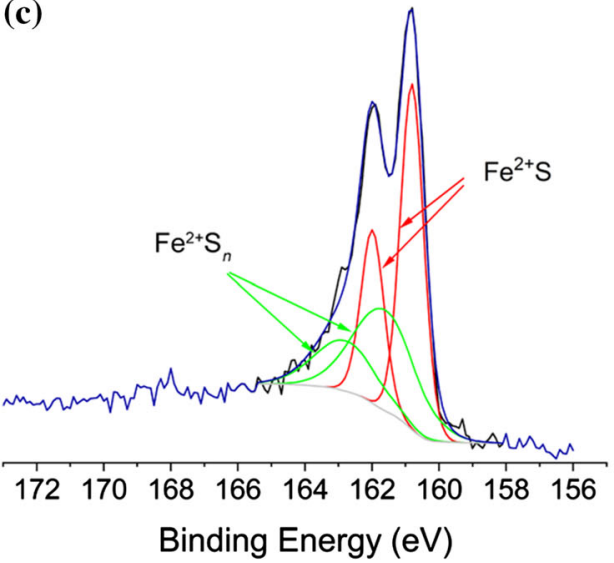

(e)

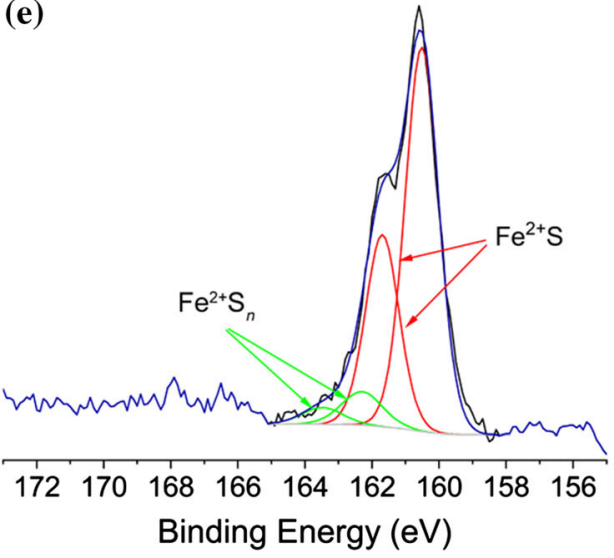

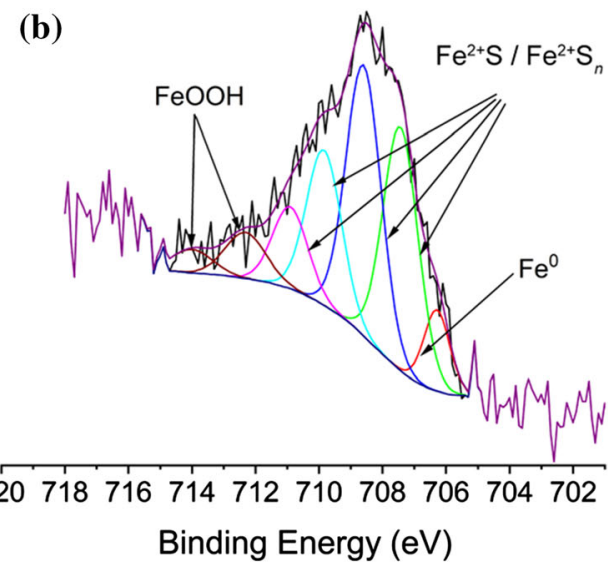

(d)

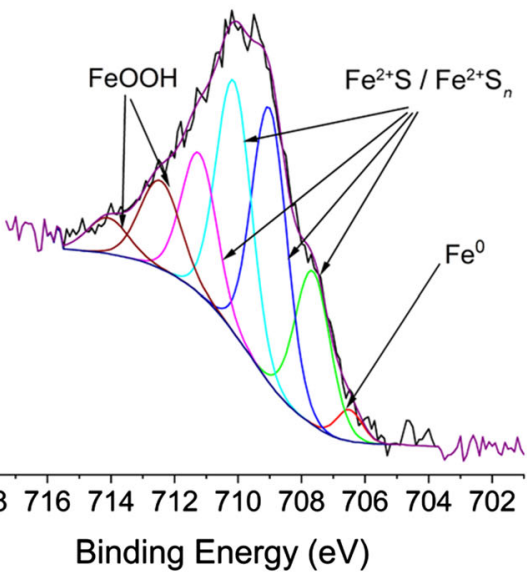

(f)

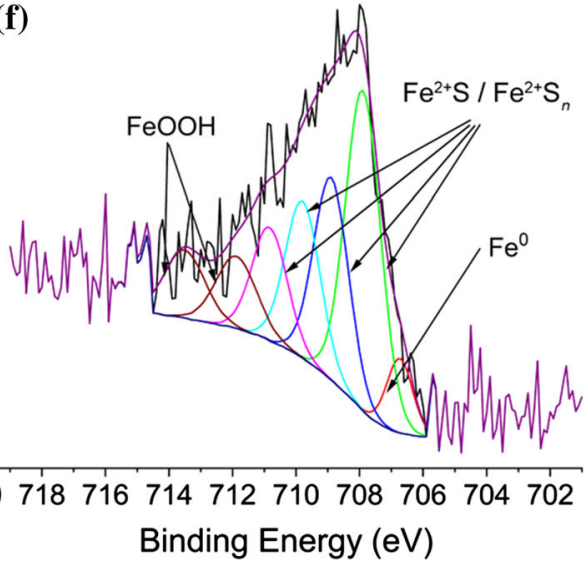

discussion of the Fe-S complex identified from the cyclic voltammograms (Fig. 1). The formation of $\mathrm{Fe}^{2+} \mathrm{S} / \mathrm{Fe}^{2+} \mathrm{S}_{n}$ in solutions containing $0.09 \mathrm{M}$ and $0.45 \mathrm{M} \mathrm{HS}^{-}$could possibly be due to the oxidation of $\mathrm{Fe}^{2+} \mathrm{S}$ species during experimentation [8, 30, 52-54].

Increasing the exposure time in each solution to 12 days and 28 days, almost no changes were observed in the $\mathrm{S} 2 p_{3 / 2}$ peaks, and $\mathrm{Fe}^{2+} \mathrm{S}$ persisted throughout the duration of exposure in solutions containing $0.09 \mathrm{M}$ and $0.45 \mathrm{M} \mathrm{HS}^{-}$(as shown in Figure S4 and Figure S5, presented in Supplementary Information). Holloway and Sykes [27] suggested that the oxidation of $\mathrm{HS}^{-}$to elemental sulfur could be possible in AAS, with implications for inhibition of pitting corrosion. However, Fig 5e (presented here), Figure S4E, and Figure S5E (in Supplementary Information) show that the surface film formed on steel exposed to $0.80 \mathrm{M} \mathrm{OH}^{-}+0.45 \mathrm{M} \mathrm{HS}^{-}$, 
replicating AAS pore fluids, contained sulfur only in the form of $\mathrm{Fe}-\mathrm{S}$ complexes without the deposition of elemental sulfur. This observation is supported by the cyclic voltammograms (Fig. 2) and the anodic polarization curves (Fig. 4), where the deposition of sulfur occurs at around $-0.05 \mathrm{~V}$ versus $\mathrm{Ag} / \mathrm{AgCl}$, and not at a potential close to the OCP, which is between -0.40 and $-0.70 \mathrm{~V}$. Therefore, it would be reasonable to only expect deposition of elemental sulfur when the surface of the steel is exposed to significant quantities of dissolved oxygen or under polarization, and not under normal circumstances when the OCP of the steel in AAS concretes is between -0.40 and $-0.70 \mathrm{~V}$.

The deconvolution of the $\mathrm{Fe} 2 p_{3 / 2}$ spectra (as shown in Fig. 5b, d, f \{presented here\}; Figure S4B, D, F; and Figure S5A, C, F \{in Supplementary Information\}) yielded peaks characteristic of $\mathrm{Fe}^{0}, \mathrm{Fe}^{2+} \mathrm{S} / \mathrm{Fe}^{2+} \mathrm{S}_{n}$ and $\mathrm{FeOOH}$ species $[8,30,52-54]$ for all exposure solutions and for all durations of exposure. The deconvolution of the $\mathrm{Fe} 2 p_{3 / 2}$ peak was much more complex, primarily due to its broad nature and the very large background observed in this energy range. Based on the analysis of the $S 2 p_{3 / 2}$ peaks observed in all electrolytes (given that much of the sulfur in solution and on the surface of steel remain in the reduced state-reflecting conditions with extremely low concentrations of dissolved oxygen) and the OCP values observed in Fig. 3a, the precipitation of $\mathrm{FeOOH}$ species in these electrolytes is highly unlikely. Thus, the Fe $2 p_{3 / 2}$ XPS features associated with $\mathrm{FeOOH}$ are primarily related to the oxidation of $\mathrm{Fe}(\mathrm{OH})_{2}$ species during experimentation/handling, which is consistent with the hypothesis of the inner layer of the surface film being comprised of $\mathrm{Fe}(\mathrm{OH})_{2}$. The data in Fig. 5b, d, f (presented here); Figure S4B, D, F; and Figure S5A, C, F (in Supplementary Information) show that upon increasing the concentration of $\mathrm{HS}^{-}$in the exposure solution, a stable $\mathrm{Fe}-\mathrm{S}$ species precipitates on the steel surface, in good agreement with the analysis of the $S 2 p_{3 / 2}$ spectra.

\section{Depassivation and its causes}

Based on the OCP and $R_{p}$ of mild steel exposed to alkaline solutions containing sulfide (Fig. $3 a, b$ ), in conjunction with the guidance of ASTM C876-15 [55] and recommendations of other authors [56, 57], it may appear an increase in the $\mathrm{HS}^{-}$concentration in the electrolyte leads to an increased susceptibility of the steel to chloride-induced corrosion. However, it must be considered that these conventional guidelines [55-57] were developed for plain Portland cement, where the electrochemical system does not contain redox-active species other than $\mathrm{Fe}^{2+}$. It is therefore very important to consider the influence of an additional redox active species (i.e., $\mathrm{HS}^{-}$) on the passive layer characteristics that determine the onset of chloride-induced corrosion. To this end, the influences of $\mathrm{HS}^{-}$and exposure time (which have been observed above to define the nature of the passive layer) on the chloride threshold value were investigated. Mild steel specimens were exposed to alkaline solutions $\left(0.80 \mathrm{M} \mathrm{OH}^{-}\right)$with varying concentrations of $\mathrm{HS}^{-}(0.001 \mathrm{M}, 0.01 \mathrm{M}, 0.09 \mathrm{M}$ and $0.45 \mathrm{M} \mathrm{HS}^{-}$) for $0,5,12$ and 28 days. After each exposure duration, the exposure solution was changed to a freshly prepared electrolytes with the same composition as the exposure solution, but with and varying chloride concentrations. OCP and anodic polarization testing were then carried out on the steel specimens.

Table 2 shows the chloride threshold values determined for mild steel exposed to alkaline sulfide solutions for various durations. The chloride threshold value in each case is defined as the concentration of chloride in the electrolyte that causes a sudden rise in the current density upon the anodic polarization of mild steel from its OCP to $+1.00 \mathrm{~V}$ versus OCP. As given in Table 2, the chloride threshold values for mild steel are dependent on the time of exposure as well as [HS ${ }^{-}$. For mild steel exposed to an electrolyte containing $0.80 \mathrm{OH}^{-}+0.001 \mathrm{M} \mathrm{HS}^{-}$, the chloride threshold value (expressed in terms of the molar ratio $\left.\left[\mathrm{Cl}^{-}\right] /\left[\mathrm{OH}^{-}\right]\right)$was observed to increase significantly from 0.70 at 0 days, to a value $>3.50$ (the maximum $\left[\mathrm{Cl}^{-}\right] /\left[\mathrm{OH}^{-}\right]$achievable in the electrolyte due to solubility limitations) at 5 days or more. When the steel was exposed to electrolytes containing intermediate concentrations of $\mathrm{HS}^{-}(0.01 \mathrm{M}$ and $0.09 \mathrm{M})$, the chloride threshold values were found to vary as a function of time, and no apparent relationship between exposure time and chloride threshold value was observed. Interestingly and surprisingly, chloride-induced corrosion or pitting was not observed on mild steels exposed to electrolytes contained $0.45 \mathrm{M} \mathrm{HS}^{-}$at any chloride content tested up to saturation, independent of exposure time. These observations are sharp contrast with the OCP and $R_{p}$ values (Fig. 3a, b) for steel in alkaline solutions 
Table 2 Influence of $\left[\mathrm{HS}^{-}\right]$and exposure time on the "chloride threshold" value of mild steel, represented as the molar ratio $\left[\mathrm{Cl}^{-}\right] /$ $\left[\mathrm{OH}^{-}\right]$which induces pitting corrosion, as determined using anodic polarization. Cases where chloride-induced corrosion was not observed for electrolytes with $\left[\mathrm{Cl}^{-}\right] /\left[\mathrm{OH}^{-}\right]=3.5$ have been classified as "No Pitting"

\begin{tabular}{|c|c|c|c|c|c|c|}
\hline $\begin{array}{l}\text { Exposure } \\
\text { time }\end{array}$ & $\begin{array}{l}0.80 \mathrm{M} \\
\mathrm{OH}^{-}+0.001 \mathrm{M} \\
\mathrm{HS}^{-}\end{array}$ & $\begin{array}{l}0.80 \mathrm{M} \\
\mathrm{OH}^{-}+0.01 \mathrm{M} \\
\mathrm{HS}^{-}\end{array}$ & $\begin{array}{l}1.12 \mathrm{M} \\
\mathrm{OH}^{-}+0.01 \mathrm{M} \\
\mathrm{HS}^{-}\end{array}$ & $\begin{array}{l}1.36 \mathrm{M} \\
\mathrm{OH}^{-}+0.01 \mathrm{M} \\
\mathrm{HS}^{-}\end{array}$ & $\begin{array}{l}0.80 \mathrm{M} \\
\mathrm{OH}^{-}+0.09 \mathrm{M} \\
\mathrm{HS}^{-}\end{array}$ & $\begin{array}{l}0.80 \mathrm{M} \\
\mathrm{OH}^{-}+0.45 \mathrm{M} \\
\mathrm{HS}^{-}\end{array}$ \\
\hline 0 days & 0.7 & 2.5 & 2.7 & 2.8 & 3.1 & No pitting \\
\hline 5 days & No pitting & 3 & 2.9 & 3.1 & 3 & No pitting \\
\hline 12 days & No pitting & 2.8 & 2.3 & 2.8 & 3 & No pitting \\
\hline 28 days & No pitting & 2 & 2.2 & 2.6 & 3.2 & No pitting \\
\hline
\end{tabular}

containing $0.01 \mathrm{M}, 0.09 \mathrm{M}$ and $0.45 \mathrm{M} \mathrm{HS}^{-}$without chloride, as a lower OCP and $R_{p}$ would conventionally be taken to indicate a higher susceptibility to corrosion.

Figure 6 shows the OCP of mild steel as a function of the concentrations of $\mathrm{HS}^{-}, \mathrm{OH}^{-}$, and $\mathrm{Cl}^{-}$in the electrolyte, and of the time of exposure. In line with observations from Fig. 3a, b, the OCP (Fig. 6) was observed to decrease with an increase in $\left[\mathrm{HS}^{-}\right] /$ $\left[\mathrm{OH}^{-}\right]$, but the OCP values in Fig. 6 are very similar

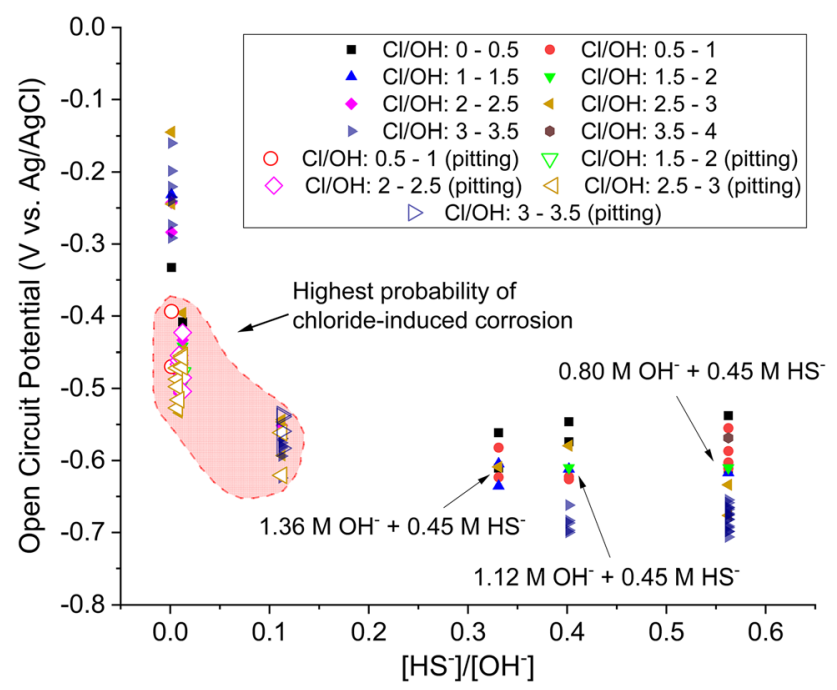

Figure 6 OCP of mild steel exposed to highly alkaline solutions $\left(0.80 \mathrm{M}, 1.12 \mathrm{M}\right.$ and $\left.1.36 \mathrm{M} \mathrm{OH}^{-}\right)$, with varying concentrations of $\mathrm{HS}^{-}(0.001 \mathrm{M}, 0.01 \mathrm{M}, 0.09 \mathrm{M}$ and $0.45 \mathrm{M})$ and $\mathrm{Cl}^{-}(0-4$ in terms of $\left.\left[\mathrm{Cl}^{-}\right] /\left[\mathrm{OH}^{-}\right]\right)$, after $0,5,12$ and 28 days exposure. The solid symbols denote the steel samples exhibiting no corrosion, whereas the hollow symbols indicate stable or metastable chloride-induced pitting. The transparent red shaded area in (A) indicates the region where the susceptibility to chloride-induced corrosion is the highest. to those observed for steel immersed in solutions without chloride, Fig. 3a. This indicates that the chloride concentration in sulfide-containing alkaline solutions has negligible influence on the $\mathrm{OCP}$, unlike the behavior of steel in alkaline sulfide-free solutions [10] where the OCP suddenly decreases when the chloride concentration in the electrolyte reaches a given threshold value. The absence of such an effect in the presence of sulfide is particularly clear from the very similar OCP values of steel samples that exhibit chloride-induced pitting, and those are passive, at $\left[\mathrm{HS}^{-}\right]=0.01 \mathrm{M}$ and $0.09 \mathrm{M}$ (shaded red region in Fig. 6). Chloride-induced pitting was observed mostly in electrolytes with molar ratios $\left[\mathrm{HS}^{-}\right] /\left[\mathrm{OH}^{-}\right]$between 0.007 and 0.1125 , which is identified as the region where the probability of steel undergoing chloride-induced pitting is the highest among all the electrolytes considered in this study.

Similar observations have been made by several authors for steel embedded in AAS and PC. Holloway and Sykes [27] studied the corrosion behavior of steel in AAS mortars containing admixed chloride, and did not observe well-defined trends for either $i_{\text {corr }}$ or OCP as a function of the chloride concentration. The OCP values in their AAS mortars with chloride concentrations as high as 8 wt \% remained as low as those observed in mortars containing no chloride [27]. Criado et al. [50] identified that for steel-reinforced AAS, immersion of mortar specimens in alkaline solutions with and without chloride made no difference to the measured OCP values, which remained at around $-0.60 \mathrm{~V}$ versus $\mathrm{Ag} /$ $\mathrm{AgCl}$. Higher apparent corrosion rates [58], higher $i_{\text {corr }}$ and lower $R_{p}$ values $[48,50]$, but without any visual evidence of corrosion, have also been reported for steel-reinforced AAS exposed to chloride 
solutions, in comparison with the measurements of these parameters in PC specimens. This leads to the conclusion that under reducing conditions and in the presence of dissolved $\mathrm{HS}^{-}$, measured values of $R_{p}$ and calculated values of $i_{\text {corr }}$ (Figure S7, Supplementary Information) are determined by the aqueous chemistry of the electrolyte at the steel-solution interface, and not necessarily the actual corrosion resistance of the steel. In particular, these values correspond mainly to the oxidation of the $\mathrm{HS}^{-}$species in the electrolyte (and not exclusively to the redox couple of $\mathrm{Fe} / \mathrm{Fe}^{2+}$ ), which takes place because of the potential imposed in the electrochemical test procedure used to determine these parameters.

This has been confirmed by the anodic polarization behavior of iridium (Figure S6) and steel in alkaline sulfide-containing solutions (Fig. 4), where the anodic polarization curves were characterized by a continuous increase in the current density when increasing the potential in the anodic direction from the OCP. This rise in the current density is primarily because the $\mathrm{HS}^{-}$in the electrolyte, due to its high polarizability, becomes the anode instead of Fe. This phenomenon is analogous to the action of some bacteria that are capable of depleting the oxygen content in an electrolyte and create a highly reducing environment around the metal $[59,60]$. This leads to the suppression of the cathodic reduction of oxygen and a slowdown in the dissolution of metal ions; in such systems, the bacteria act as the anode [61].

From the results shown in Fig. 6 and Figure S7 (Supplementary Information), and the body of literature data [27, 48-50, 58, 62], it is evident that the mechanisms of chloride-induced corrosion of mild steel in alkaline solutions containing $\mathrm{HS}^{-}$are much complex than those in sulfide-free solutions. Thus, the conventional electrochemical tools applied to the detection of corrosion of steel reinforcement in concretes, being OCP measurements, application of LPR to determine $R_{p}$, and calculation of $i_{\text {corr }}$ from the modified Stern-Geary equation (Eq. 2), do not give useful information about whether the steel is at risk of chloride-induced pitting.

An increase in the concentration of reduced sulfur in the electrolyte leads to a decrease in the amount of dissolved oxygen at the steel-solution interface, and consequentially a reduction in the OCP [14] (Fig. 3a). This will inhibit the development of a passive film based on iron oxides, as is conventionally observed in sulfide-free alkaline solutions. Instead, as shown in
Fig. 1, a sulfidic surface film develops. The suppression of the cathodic reduction in oxygen prevents the formation of a macro-cell on the surface of the steel and would restrict the onset of chloride induced corrosion. The inhibition of macro-cell formation is highly dependent on the concentration of $\mathrm{HS}^{-}$in the electrolyte: for a given concentration of chloride, the susceptibility to chloride-induced corrosion is the highest when the molar ratio of $\left[\mathrm{HS}^{-}\right] /\left[\mathrm{OH}^{-}\right]$in the electrolyte is between 0.007 and 0.1125 (mildly reducing), and the lowest for electrolytes with molar ratios of $\left[\mathrm{HS}^{-}\right] /\left[\mathrm{OH}^{-}\right] \geq 0.33$ (highly reducing).

Based on pore fluid extraction data available in the literature $[2,3,63]$, the mildly reducing electrolytes $\left(\left[\mathrm{HS}^{-}\right] /\left[\mathrm{OH}^{-}\right]\right.$ratios between 0.007 and 0.1125 ) in this study are intended to represent pore solutions of alkali-activated fly ash-slag blends (and approach the redox environment of PC-slag blends although at a much higher alkalinity), while the highly reducing electrolytes $\left(\left[\mathrm{HS}^{-}\right] /\left[\mathrm{OH}^{-}\right] \geq 0.33\right.$ ) represent the pore solutions of AAS. The highly reducing nature of $\mathrm{HS}^{-}$ in the pore solutions of AAS does not allow the steel to passivate in the conventional way through oxide film formation, but also prevents the steel from undergoing chloride-induced pitting by suppressing the formation of a macro-cell. However, in the mildly reducing binders, the onset of pitting is much likely to occur due to the imperfect passivation capability of the binder, as well as the ability of the system to sustain the cathodic reaction of oxygen reduction, leading to the formation of a macro-cell. Similar observations have been reported by various authors $[14,26,64]$, indicating a higher susceptibility of steel to chloride-induced corrosion for binders with mildly reducing pore solutions when compared to binders with highly oxidizing or highly reducing pore solutions. However, as the onset of chloride-induced corrosion is highly dependent on the availability of dissolved oxygen at the steel-concrete interface, the transport of oxygen through the binder is also highly influential in defining the actual resistance to corrosion initiation, which is likely to account for the welldocumented excellent durability of PC-slag blends, as these cements are known to yield concretes with high mass transport resistance [65, 66]. This discussion highlights the complexity associated with using simple chemical arguments to make broad predictions related to concrete durability. Nonetheless, the key underpinning chemistry elucidated in this paper is an essential component of any such analysis. 


\section{Conclusions}

The presence of $\mathrm{HS}^{-}$in alkaline electrolytes alters not only the passivation behavior of mild steel, but also the mechanism of chloride-induced corrosion. In alkaline solutions containing sulfide, the competitive adsorption of $\left[\mathrm{OH}^{-}\right]$and $\left[\mathrm{HS}^{-}\right]$inhibits and retards the formation of a passive film composed of iron oxides, and instead forms an Fe-S complex. In these solutions, the mechanism of forming a surface film can be described as:

$$
\begin{aligned}
\mathrm{Fe}+\mathrm{OH}^{-}+\mathrm{HS}^{-} \rightarrow & \mathrm{Fe}(\mathrm{OH})_{\text {ads }}+\mathrm{Fe}(\mathrm{HS})_{\text {ads }} \\
\rightarrow & \mathrm{Fe}(\mathrm{OH})_{\text {ads }}^{+}+\mathrm{Fe}(\mathrm{HS})_{\text {ads }}^{+} \\
\rightarrow & \mathrm{Fe}(\mathrm{OH})_{2}+\mathrm{Fe}(\mathrm{HS})_{2, \text { ads }} \\
\rightarrow & \text { hydrated FeOOH and } \mathrm{Fe} \\
& -\mathrm{S} \text { complex }
\end{aligned}
$$

The likelihood of formation of a hydrated $\mathrm{FeOOH}$ layer is high when the concentration of $\mathrm{HS}^{-}$in the electrolyte is below $0.01 \mathrm{M}$. In the case of alkaline solutions with $\left[\mathrm{HS}^{-}\right] \geq 0.09 \mathrm{M}$, the surface film is characterized by a stable Fe-S complex. Therefore, passivation in these electrolytes strongly depends on the availability of dissolved oxygen at the steel-solution interface.

Chloride-induced corrosion was observed to occur only for steel exposed to solutions with $\left[\mathrm{HS}^{-}\right] /\left[\mathrm{OH}^{-}\right]$ between 0.007 and 0.1125 at the alkalinity levels studied here $(\mathrm{NaOH}$ concentrations from 0.80 to $1.36 \mathrm{M}$ ), when testing chloride concentrations up to saturation with respect to $\mathrm{NaCl}$. In solutions with $\left[\mathrm{HS}^{-}\right] /\left[\mathrm{OH}^{-}\right] \geq 0.33$, intended to represent the pore solutions of alkali-activated slag cements, chlorideinduced corrosion was not observed at any chloride concentration. This was suggested to be due to the highly reducing environments created by the $\mathrm{HS}^{-}$at the steel-solution interface and the restriction of the cathodic reaction, thereby inhibiting the formation of macro-cells that would be needed to initiate pitting. This process, rather than the deposition of elemental sulfur, is responsible for the inhibition of chlorideinduced corrosion.

Additionally, it has been shown that in the presence of high concentrations of $\mathrm{HS}^{-}$, the onset of chloride induced corrosion cannot be easily detected by conventional electrochemical measurements of $R_{p}$ or $i_{\text {corr }}$, as these tend to be dominated by the oxidation of dissolved $\mathrm{HS}^{-}$upon the application of a potential. Additionally, no apparent correlation between the concentration of chloride ions in the solution and the OCP was observed. Therefore, interpretation of electrochemical data obtained for aqueous systems containing $\mathrm{HS}^{-}$based on standard guidelines that assume $\mathrm{Fe}$ to be the sole redox-active species would lead to misleading conclusions regarding whether the steel is in the passive or the active state.

\section{Acknowledgements}

The research leading to these results received funding from the European Research Council under the European Union's Seventh Framework Programme (FP/2007-2013) / ERC Grant Agreement \#335928. The authors would like to thank Prof Susan A. Bernal for useful discussions concerning simulated pore solutions of AAS, Dr Oday Hussein for helping with the preparation of the steel specimens, Dr Claire L. Corkhill for valuable discussions regarding XPS curve fitting, and Mr Dinghao Liang for helping with some of the electrochemical measurements. The authors are also grateful to Mr Gino Ebell and Mrs Tatjana Bohlmann, BAM, for helping conduct electrochemical tests on inert iridium electrodes. The authors would also like to thank Mr Kieran Nash from the Department of Civil and Structural Engineering at The University of Sheffield for providing the rebars.

\section{Author contributions}

SM and JLP conceptualized and designed the study. SM conducted experimental work and analyzed data. SM and JLP discussed results. SM drafted the manuscript with guidance from JLP. Both authors approved the final submission.

\section{Data availability}

Data can be made available upon request.

\section{Declarations}

Conflict of interest The authors declare no conflict of interest. 
Supplementary Information: The online version contains supplementary material available at http s://doi.org/10.1007/s10853-021-06237-x.

Open Access This article is licensed under a Creative Commons Attribution 4.0 International License, which permits use, sharing, adaptation, distribution and reproduction in any medium or format, as long as you give appropriate credit to the original author(s) and the source, provide a link to the Creative Commons licence, and indicate if changes were made. The images or other third party material in this article are included in the article's Creative Commons licence, unless indicated otherwise in a credit line to the material. If material is not included in the article's Creative Commons licence and your intended use is not permitted by statutory regulation or exceeds the permitted use, you will need to obtain permission directly from the copyright holder. To view a copy of this licence, visit http://creativecommons.org/licen ses/by/4.0/.

\section{References}

[1] Provis JL (2014) Geopolymers and other alkali activated materials: Why, how, and what? Mater Struct 47:11-25

[2] Gruskovnjak A, Lothenbach B, Holzer L, Figi R, Winnefeld F (2006) Hydration of alkali-activated slag: comparison with ordinary Portland cement. Adv Cem Res 18:119-128

[3] Myers RJ, Bernal SA, Provis JL (2014) A thermodynamic model for $\mathrm{C}-(\mathrm{N}-) \mathrm{A}-\mathrm{S}-\mathrm{H}$ gel CNASH_ss. Derivation and validation. Cem Concr Res 66:27-47

[4] Macphee DE, Cao HT (1993) Theoretical description of impact of blast-furnace slag (BFS) on steel passivation in concrete. Mag Concr Res 45:63-69

[5] Salvarezza RC, Videla HA, Arvia AJ (1982) The electrodissolution and passivation of mild steel in alkaline sulphide solutions. Corros Sci 22:815-829

[6] Wikjord AG, Rummery TE, Doern FE, Owen DG (1980) Corrosion and deposition during the exposure of carbon steel to hydrogen sulfide-water solutions. Corros Sci 20:651-671

[7] Cabrera-Sierra R, Miranda-Hernández M, Sosa E, Oropeza T, González I (2001) Electrochemical characterization of the different surface states formed in the corrosion of carbon steel in alkaline sour medium. Corros Sci 43:2305-2324

[8] Neal AL, Techkarnjanaruk S, Dohnalkova A, Mccready D, Peyton BM, Geesey GG (2001) Iron sulfides and sulfur species produced at hematite surfaces in the presence of sulfate-reducing bacteria. Geochim Cosmochim Acta $65: 223-235$

[9] Angst UM (2018) Challenges and opportunities in corrosion of steel in concrete. Mater Struct 51:4

[10] Mundra S, Criado M, Bernal SA, Provis JL (2017) Chlorideinduced corrosion of steel rebars in simulated pore solutions of alkali-activated concretes. Cem Concr Res 100:385-397

[11] Jayalakshmi M, Muralidharan VS (1994) Passivation and hydrogen evolution studies on iron in alkali solutions. Corros Rev 12:305-320

[12] Pourbaix M (1974) Applications of electrochemistry in corrosion science and in practice. Corros Sci 14:25-82

[13] K. Tuutti, (1982) Corrosion of steel in concrete, Swedish cement and concrete research institute, Stockholm

[14] Scott A, Alexander MG (2016) Effect of supplementary cementitious materials (binder type) on the pore solution chemistry and the corrosion of steel in alkaline environments. Cem Concr Res 89:45-55

[15] Glasser FP, Luke K, Angus MJ (1988) Modification of cement pore fluid compositions by pozzolanic additives. Cem Concr Res 18:165-178

[16] Mundra S, Bernal SA, Criado M, Hlaváček P, Ebell G, Reinemann S, Gluth GJG, Provis JL (2017) Steel corrosion in reinforced alkali-activated materials. RILEM Tech Lett 2:33-39

[17] Lorenz WJ, Heusler KE (1987) Anodic dissolution of iron group metals. In: Mansfeld F (ed) Corrosion mechanisms. Marcel Dekker, New York, pp 1-84

[18] Angus MJ, Glasser FP (1985) The chemical environment in cement matrices. Mater Res Soc Symp Proc 50:547-556

[19] Jarrah NR, Al-Amoudi OSB, Maslehuddin M, Ashiru OA, Al-Mana AI (1995) Electrochemical behavior of steel in plain and blended cement concretes in sulphate and/or chloride environments. Constr Build Mater 9:97-103

[20] Angst U, Elsener B, Larsen CK, Vennesland Ø (2009) Critical chloride content in reinforced concrete-a review. Cem Concr Res 39:1122-1138

[21] Schiessl P, Breit W (1996) Local repair measures at concrete structures damaged by reinforcement corrosion-aspects of durability. In: Page CL (ed) 4th international symposium on corrosion of reinforcement in concrete construction. Royal society of chemistry, Cambridge UK, pp 525-534

[22] Schiessl P, Breit W (1997) Investigation on the threshold value of the critical chloride content. In: Malhotra VM (ed) Fourth CANMET/ACI conference on the durability of concrete. American Concrete Institute, Sydney, pp 363-378

[23] Gouda VK, Halaka WY (1970) Corrosion and corrosion inhibition of reinforcing steel: II. Embedded in concrete. $\mathrm{Br}$ Corros J 5:204-208 
[24] Gouda VK, Shater MA, Mikhail RS (1975) Hardened portland blast-furnace slag cement pastes II. The corrosion behavior of steel reinforcement. Cem Concr Res 5:1-13

[25] Oh BH, Jang SY, Shin YS (2003) Experimental investigation of the threshold chloride concentration for corrosion initiation in reinforced concrete structures. Mag Concr Res 55:117-124

[26] Babaee M, Castel A (2018) Chloride diffusivity, chloride threshold, and corrosion initiation in reinforced alkali-activated mortars: role of calcium, alkali, and silicate content. Cem Concr Res 111:56-71

[27] Holloway M, Sykes JM (2005) Studies of the corrosion of mild steel in alkali-activated slag cement mortars with sodium chloride admixtures by a galvanostatic pulse method. Corros Sci 47:3097-3110

[28] ISO/DIS 6935-2, (2015) Steel for the reinforcement of concrete-part 2: ribbed bars, International organization for standardization

[29] Ghods P, Isgor OB, Brown JR, Bensebaa F, Kingston D (2011) XPS depth profiling study on the passive oxide film of carbon steel in saturated calcium hydroxide solution and the effect of chloride on the film properties. Appl Surf Sci 257:4669-4677

[30] Matamoros-Veloza A, Cespedes O, Johnson BRG, Stawski TM, Terranova U, de Leeuw NH, Benning LG (2018) A highly reactive precursor in the iron sulfide system. Nat Commun 9:3125

[31] Nesbitt HW, Muir IJ (1994) X-ray photoelectron spectroscopic study of a pristine pyrite surface reacted with water vapour and air. Geochim Cosmochim Acta 58:4667-4679

[32] Shoesmith DW, Taylor P, Bailey MG, Ikeda B (1978) Electrochemical behaviour of iron in alkaline sulphide solutions. Electrochim Acta 23:903-916

[33] Vera J, Kapusta S, Hackerman N (1986) Localized corrosion of iron in alkaline sulfide solutions. J Electrochem Soc 133:461-467

[34] Chanson C, Blanchard P, Wattiaux A, Grenier J-C (1989) A ring-disk study of electrochemical behavior of iron in strong alkaline medium: influence of additive sulfide ions. J Electrochem Soc 136:3690-3695

[35] Liu Y, Liu H, Guo X, Hu N (2010) Influence of ionic strength on electrochemical responses of myoglobin loaded in polysaccharide layer-by-layer assembly films. Electroanalysis 22:2261-2268

[36] Macdonald DD, Roberts B (1978) The cyclic voltammetry of carbon steel in concentrated sodium hydroxide solution. Electrochim Acta 23:781-786

[37] Schrebler Guzman RS, Vilche JR, Arvia AJ (1979) The potentiodynamic behaviour of iron in alkaline solutions. Electrochim Acta 24:395-403
[38] Tromans D (1980) Anodic polarization behavior of mild steel in hot alkaline sulfide solutions. J Electrochem Soc 127:1253-1253

[39] Von Kaesche H (1970) Elektrochemische untersuchungen über die korrosion des eisens in sulfidhaltigen lösungen (in German). Mater Corros Werkstoffe Und Korrosion 21:185-195

[40] Shoesmith DW, Bailey MG, Ikeda B (1978) Electrochemical formation of mackinawite in alkaline sulphide solutions. Electrochim Acta 23:1329-1339

[41] Chen KY, Morris JC (1972) Kinetics of oxidation of aqueous sulfide by $\mathrm{O}_{2}$. Environ Sci Technol 6:529-537

[42] Lefers JB, Koetsier WT, Van Swaaij WPM (1978) The oxidation of sulphide in aqueous solutions. Chem Eng $\mathrm{J}$ $15: 111-120$

[43] Brennan MPJ (1977) The anodic evolution of sulphur from sodium polysulphide melts-I. Voltammetric measurements on planar carbon electrodes. Electrochim Acta 22:279-283

[44] Ramasubramanian N (1975) Anodic behavior of platinum electrodes in sulfide solutions and the formation of platinum sulfide. J Electroanal Chem 64:21-37

[45] Avrahami M, Golding R (1968) The oxidation of the sulfide ion at very low concentrations in aqueous solutions. J Chem Soc A Inorg Phys Theor. https://doi.org/10.1039/ j19680000647

[46] Calandra AJ, de Tacconi NR, Pereiro R, Arvia AJ (1974) Potentiodynamic current/potential relations for film formation under ohmic resistance control. Electrochim Acta 19:901-905

[47] Garcia V, François R, Carcasses M, Gegout P (2013) Potential measurement to determine the chloride threshold concentration that initiates corrosion of reinforcing steel bar in slag concretes. Mater Struct 47:1483-1499

[48] Tennakoon C, Shayan A, Sanjayan JG, Xu A (2017) Chloride ingress and steel corrosion in geopolymer concrete based on long term tests. Mater Des 116:287-299

[49] Criado M, Provis JL (2018) Alkali activated slag mortars provide high resistance to chloride-induced corrosion of steel. Front Mater 5:34

[50] M. Criado, S. Mundra, S.A. Bernal, J.L. Provis, (2017) A study on the passive state stability of steel embedded in alkali activated slag mortars, In: 14th International conference on the durability of building materials and components (XIV DBMC), Ghent, Belgium.

[51] Andrade C, Alonso C (1996) Corrosion rate monitoring in the laboratory and on-site. Constr Build Mater 10:315-328

[52] Jones CF, LeCount S, Smart RSC, White TJ (1992) Compositional and structural alteration of pyrrhotite surfaces in solution: XPS and XRD studies. Appl Surf Sci 55:65-85 
[53] Herbert RB Jr, Pratt AR, Blowes DW, Benner SG (1998) Surface oxidation of iron monosulphide: an X-ray photoelectron spectroscopic study. Mineral Mag 62A:608-609

[54] Buckley AN, Woods R (1985) X-ray photoelectron spectroscopy of oxidised pyrrhotite surfaces. Appl Surf Sci $20: 472-480$

[55] ASTM C876-15, (2015) Standard test method for corrosion potentials of uncoated reinforcing steel in concrete, ASTM International

[56] Andrade C, González JA (1978) Quantitative measurements of corrosion rate of reinforcing steels embedded in concrete using polarization resistance measurements. Mater Corros 29:515-519

[57] Andrade C, Alonso MC, González JA (1990) An initial effort to use the corrosion rate measurements for estimating rebar durability. In: Berke N, Chaker V, Whiting D (eds) corrosion rates of steel in concrete, ASTM STP 1065. ASTM International, PA, pp 29-37

[58] Ma Q, Nanukuttan SV, Basheer PAM, Bai Y, Yang C (2016) Chloride transport and the resulting corrosion of steel bars in alkali activated slag concretes. Mater Struct 49:3663-3677

[59] Videla HA, Herrera LK (2009) Understanding microbial inhibition of corrosion. A comprehensive overview. Int Biodeterior Biodegrad 63:896-900
[60] Zuo R (2007) Biofilms: strategies for metal corrosion inhibition employing microorganisms. Appl Microbiol Biotechnol 76:1245-1253

[61] Pedersen A, Hermansson M (1991) Inhibition of metal corrosion by bacteria. J Bioadhesion Biofilm Res 3:1-11

[62] Criado M, Bernal SA, Garcia-Triñanes P, Provis JL (2018) Influence of slag composition on the stability of steel in alkali-activated cementitious materials. J Mater Sci 53:5016-5035. https://doi.org/10.1007/s10853-017-1919-3

[63] Vollpracht A, Lothenbach B, Snellings R, Haufe J (2016) The pore solution of blended cements: a review. Mater Struct 49:3341-3367

[64] Robineau M, Sabot R, Jeannin M, Deydier V, Crusset D, Refait P (2021) Mechanisms of localized corrosion of carbon steel associated with magnetite/mackinawite layers in a cement grout. Mater Corros 72:194-210

[65] Olsson N, Lothenbach B, Baroghel-Bouny V, Nilsson LO (2018) Unsaturated ion diffusion in cementitious materialsThe effect of slag and silica fume. Cem Concr Res 108:31-37

[66] Osborne GJ (1999) Durability of Portland blast-furnace slag cement concrete. Cem Concr Compos 21:11-21

Publisher's Note Springer Nature remains neutral with regard to jurisdictional claims in published maps and institutional affiliations. 